\title{
Performance on the Novel Bound-Morpheme Generalization (NBMG) Task in Korean-English Bilingual Children
}

\author{
Yeonjoo Jo, Dongsun Yim \\ Department of Communication Disorders, Ewha Womans University, Seoul, Korea
}

Correspondence: Dongsun Yim, PhD Department of Communication Disorders, Ewha Womans University, 52 Ewhayeodae-gil, Seodamun-gu, Seoul 03760, Korea

Tel: $+82-2-3277-6720$

Fax: $+82-2-3277-2122$

E-mail: sunyim@ewha.ac.kr

Received: October 5, 2016

Revised: November 29, 2016

Accepted: December 28, 2016

This work was supported by the Ewha Womans University Research Grant of 2015.

\begin{abstract}
Objectives: The standard evaluation tools widely used today cannot accurately assess the learning ability of bilingual children. For this reason, we produced the Novel Bound-Morpheme Generalization task (NBMG) in both English and Korean to measure bilingual children's ability to learn morphemes. Methods: The age of the subjects ranged from 4 years and 6 months to 7 years old. There were 30 normally developing Korea-English bilinguals, 30 normally developing Korean monolinguals, and 20 Korean monolinguals with language impairment. For the bilinguals, both Korean NBMG (KNBMG) and English NBMG (ENBMG) tests were conducted, while for the monolinguals only KNBMG was conducted. Results: First, for the KNBMG, the performance of Korean monolinguals with language impairment was noticeably poorer than bilinguals and normal Korean monolinguals. Second, for the bilingual children, there was a noticeable correlation between their KNBMG performances and REVT total scores, and between KNBMG and ENBMG performances. Conclusion: In conclusion, NBMG was proven to be an effective evaluation tool for identifying children with language impairment; a poor performance on KNBMG may reasonably lead to suspicion of language impairment. It further suggests that measuring children's language ability through a task created in a single language is effective when the language is shared by the bilingual children and the speech language pathologist.
\end{abstract}

Keywords: Bilingual children, Dynamic assessment, Language disorder, Morpheme
국내에서 영어의 사회적 영향이 높아짐에 따라 조기 영어 교육 의 확산이 증가가 되면서, 많은 교육기관에서 영어를 습득하는 순 차적(sequential) 이중언어 아동이 늘고 있다(Lee \& Lee, 2005). 순 차적(sequential) 이중언어 아동이란, 한 번에 두 가지 이상의 언어 (모국어와 제 2 언어)를 습득하는 동시적(simultaneous) 이중언어 아동과는 달리 모국어를 먼저 습득한 후에 약 3 세 이후부터 제 2 언 어를 습득하는 아동을 이중언어 아동이라 정의한다(Kohnert, 2008; Lambert, 1977).

이러한 이중언어 아동의 언어 능력은 언어습득 환경, 아동의 모 국어 능력, 언어 노출시간, 아동의 발달 정도, 부모의 경제적 지위, 사용 언어의 사회적 지위 등이 다양하게 변수에 영향을 받으며(Bialystok, 2001; Bloomfield, 1933; Hakuta, 1986), 이 중 언어의 사회
적 지위는 아동이 사용하는 언어가 다수언어(majority language) 인지, 소수언어(minority language) 인지에 따라 결정되고, 이러한 사회적 지위는 해당 언어의 유창성과 비유창성을 결정하게 된다 (Genesee, Paradis, \& Crago, 2004).

특히, 한국어-영어 이중언어 아동과 같은 순차적 이중언어 아동 은 단일언어 사용 아동과는 달리 언어발달 과정 중 언어의 전환 (code switching), 간섭(interference), 손실(language loss) 등의 현 상을 겪게 된다(Hong \& Yim, 2014). 이러한 현상은 자연스러운 이 중언어 사용 아동의 특징이지만 이중언어 아동의 언어발달에 대한 이해가 부족하여, 언어장애로 오해를 받는 경우가 상당하다(Kohnert, 2010; Pearson, Fernandez, Lewedeg, \& Oller, 1997). 그러므로 이러한 오진을 막기 위해서는 다양한 언어를 습득하면서 나타나는 
현상인지, 언어 기저에 문제가 있는 것인지 판단하는 것이 상당히 중요하지만 이를 평가할 타당한 규준이나 진단 도구가 존재하지 않 는다(Kohnert, 2010).

뿐만 아니라, 이중언어 아동의 언어능력을 평가하기 위해서는 아 동이 사용하는 두 가지 이상의 언어를 모두 평가해야 하지만(Kohnert, 2010), 현실적으로 큰 제약이 있기 때문에, 한 언어권의 표준 화 검사도구만으로 평가하는 것이 일반적이다(Caesar \& Kohler, 2007). 이 경우 평가하지 못한 다른 언어능력은 배제되기 때문에 아 동의 정확한 언어능력을 평가하기 어렵다.

그러나 이중언어 아동이 사용하는 두 가지 이상의 언어를 모두 표준화 진단도구로 평가한다고 해서 아동의 언어능력을 정확히 판 단할 수 있다는 것을 의미하지는 않는다. 표준화 도구는 해당 언어 의 사용빈도, 어휘 난이도, 품사 비율, 문화 및 지역별 사용 특성을 고려하여 구성되기 때문에, 다양한 문화와 언어를 경험하는 이중 언어 아동들에게는 표준화 진단도구는 적합하지 않다(Kayser, 1995; Langdon, 1992).

이러한 문제점을 해결하기 위해 두 가지 언어를 동시에 사용하여 아동의 어휘 개념이해를 파악하는 합산점수(composite scoring) 방식에 대한 연구가 있다(Kohnert, Hernandez, \& Bates, 1998). 한 언어권의 표준화 어휘검사도구를 실시할 때, 하나의 언어가 아닌, 두 언어로 모두 평가하여 정반응을 보이면 1점을 부여하는 방식이 며, 각 언어별 어휘 능력이 아닌 이중언어 아동의 실제 어휘 크기 (vocabulary size)를 파악할 수 있는 방식이다(Kohnert et al., 1998; Pearson et al., 1997; Pearson, 2007). 이중언어 아동은 각각 경험한 문화 및 언어들의 비율이 매우 상이하므로, 개인별로 특정 언어가 차지하는 비율이 매우 다양하다. 그러므로 한 언어권의 표준화 검 사도구로 산출된 결과가 아동의 언어 능력을 얼마나 나타내고 있 는지는 가늠할 수 없고, 언어 능력을 진단할 방법이 없기 때문에, 두 가지 언어를 합산하여 평가하는 방식은 이중언어 아동의 발달지체 과잉진단을 상대적으로 줄일 수 있다고 보고되고 있다(Kohnert et al., 1998; Yim, Yoon, \& Lee, 2016).

국내에서도 합산점수(composite scoring)에 관한 연구가 진행되 고 있으며(Yim, Yoon, et al., 2016), 현재 이중언어 아동의 언어 능력 평가를 위한 타당한 규준이 존재하지 않기 때문에, 다양한 연구에 서 연구대상 집단을 분류하기 위한 선별검사로 합산점수(composite scoring)를 사용하고 있다(Hong \& Yim, 2014; Yim, Jo, Han, \& Seong, 2016). 그러나 합산점수(composite scoring) 방식은 기존의 표준화 어휘검사도구와 마찬가지로 검사자가 두 가지 언어에 능숙 해야 한다는 한계점을 지니고 있다(Yim, Yoon, et al., 2016).

이와 같은 이중언어 아동 언어 평가의 문제점을 보완하기 위해,
아동의 표면적 언어 능력만을 평가하는 것이 아닌 언어발달 기제 를 평가하기 위한 '인지 처리 과제(cognitive processing tasks)' 연구 가 진행 되고 있는데(Dollaghan \& Campbell, 1998; Welsh \& Pennington, 1998; Yim, 2011), 인지 정보 처리 능력으로는 집행기능 (executive function), 작업기억(working memory), 선택적 주의집 중(sustained selective attention), 정보 처리 속도(speed of information processing), 학습 능력(learnability) 등이 있으며, 이를 비언어 적 처리 과제와 언어적 처리 과제로 나누어 많은 연구가 진행되어 왔다(Baddeley \& Hitch, 1974; Connell, 1987; Kohnert, 2008; Miller, Kail, Leonard, \& Tomblin, 2001; Spaulding, Plante, \& Vance, 2008).

비언어적 처리 과제는 상호적 정보 처리 이론(interactive processing information theory)이 기반이 되는 언어 능력을 판단하기 위한 과제로써(Yim, Kohnert, \& Windsor, 2005), 시공간 작업기억 용량을 측정하는 매트릭스(matrix)과제(Gathercole \& Pickering, 2000)와 음운 단기기억을 측정하는 과제인 비단어 따라말하기 (non-word repetition) (Gathercole \& Baddeley, 1990) 등이 있으며, 매트릭스(matrix)를 사용한 선행연구에서 언어에 문제를 보이는 아동의 수행력이 현저히 낮았고(Montgomery, 1993), 음운 작업기 억을 측정하는 비단어 따라말하기(non-word repetition)에서도 언 어발달지연 아동은 음운규칙 처리에 한계를 보였다(Briscoe, Bishop, \& Norbury, 2001; Caplan \& Waters, 1999; Eadie, Fey, Douglas, \& Parsons, 2002; Gathercole \& Baddeley, 1990; Swanson \& SachseLee, 2001). 단일언어 뿐만 아니라 이중언어 일반 아동을 포함한 선 행연구에서도 비단어 따라말하기(non-word repetition) 과제에서 언어발달지연 아동의 수행력이 유의하게 낮으며(Windsor, Kohnert, Loxtercamp, \& Kan, 2008), 이중언어 일반 아동과 이중언어 언어 발달지연 아동을 대상으로 비언어적 통계적 학습 과제를 진행한 연구에서도 언어발달지연 아동의 수행력의 한계를 보였다(Evans, Saffran, \& Robe-Torres, 2009).

언어적 처리 과제로는 동시에 저장(storage)과 처리(processing) 가 발생시킴으로써 작업기억 용량을 측정하는 경쟁적 언어처리 과 제(Competing Language Processing Tasks, CLPT)와, 빠른 낱말 연결하기(fast mapping) 능력을 평가하는 새로운 무의미 어휘 학습 과제(Dollaghan, 1987; Oetting, Rice, \& Swank, 1995), 그리고 형태 소 학습 능력을 측정하는 새로운 의존형태소 일반화 과제(Novel Bound-Morpheme Generalization, NBMG; Roseberry \& Connell, 1991)가 있다.

경쟁적 언어처리 과제(CLPT)에서 언어에 어려움이 있는 아동이 정오 판단과 단어 회상의 수행 능력이 유의미하게 낮았으며, 새로운 
무의미 어휘를 사용한 과제(Dollaghan, 1987; Oetting et al., 1995) 를 사용한 연구에서도 언어발달지연 아동이 일반 아동에 비해 무 의미 어휘 습득이 유의미하게 늦었다. 마지막으로 형태소 학습 능 력을 평가하는 새로운 의존형태소 일반화 과제(NBMG)를 사용한 연구에서도 이중언어 언어발달지연 아동들의 수행 능력이 낮은 것 으로 나타났다(Connell \& Stone, 1992).

이 결과는 언어발달지연 아동이 언어성 및 비언어성 정보 처리의 어려움이 있으며(Evans et al., 2009), 전반적인 학습 전략에서도 문 제가 있다는 것을 나타나기 때문에(Evans et al., 2009), 언어성 및 비언어성 정보 처리 능력을 활용하여, 이중언어 아동의 언어능력을 평가할 수 있다는 것을 나타내고 있다.

그러나 매트릭스(matrix)같은 비언어적 과제 수행 시 언어발달 이 지연된 아동과 일반 아동 사이에 수행력 차이가 유의하지 않다 는 연구 결과가 있으며(Archibald \& Gathercole, 2006; Williams, Stott, Goodyer, \& Sahakian, 2000), 비단어 따라말하기(Non-word repetition)과제는 어휘 능력을 요구하지 않은 과제이지만(Kohnert, Windsor, \& Yim, 2006), 이중언어 아동 대상 연구에서는 언어적 경 험을 배제하기 어렵기 때문에, 언어 능력을 파악하는 것이 힘들다 는 선행연구도 있다(Gutiérrez-Clellen \& Simon-Cereijido, 2010).

이처럼 인지 처리 과제(cognitive processing tasks)가 이중언어 아동의 언어장애 진단 여부를 위한 평가도구로 사용될 수 있는지 에 대한 의견이 나뉘고 있으므로, 이중언어 아동을 대상으로 하는 다양한 인지 처리 과제(cognitive processing tasks) 연구가 요구되 고 있다.

인지 처리 과제(cognitive processing tasks) 중 새로운 의존형태 소 일반화 과제(NBMG)는 이중언어 아동을 대상으로 많은 연구들 이 진행되었다(Hwa-Froelich \& Matsuo, 2005; Kohnert \& Danahy, 2007; Roseberry \& Connell, 1991). 새로운 의존형태소 일반화 과제 (NBMG)는 아동의 학습 능력(learnability)(Kohnert, 2010)을 측정 하는 과제로, 현재 표면에 나타나는 언어 능력이 아닌 얼마나 학습 할 수 있는지에 초점을 맞추고 있다. 특히 언어발달지연 아동에게 어려움이 있다고 알려진 형태소 학습 능력을 측정하면서(Anderson, 2001; Kohnert, 2010), 언어 경험이 아닌 언어 능력의 평가가 필 요한 이중언어 아동을 대상으로 주로 시행되었다.

형태소를 인식하고 학습할 수 있는 능력은 의식적으로 단어 내 에 있는 형태소에 대해 생각하며 조정할 때 발생하는 메타언어 인 식 능력을 포함하고 있다(Apel, Diehm, \& Apel, 2013). 메타언어 인 식(metalinguistic awareness)이란 언어 자체의 구조적 특성에 대해 서 생각하고 조작할 수 있는 능력을 뜻하고(Van Kleeck, 1982), 언 어의 사용, 학업 성취, 인지발달, 지능, 읽기 능력과 상응하여 발달
한다고 보고되었다(Kemper \& Venooy, 1993). 이러한 메타언어 인 식 능력을 나타내는 형태소 인식 능력은 읽기 능력과 쓰기 능력에 큰 영향을 미치므로(Wang, Ko, \& Choi, 2009; Wolter, Wood, \& D'zatko, 2009), 학습부진 아동의 형태소 인식 능력이 일반 아동에 비해 낮은 수행력을 나타낸다고 보고되고 있다(Park, 2012).

이중언어 언어발달지연 아동이 이러한 ‘형태소 학습 능력'에 제 한이 있다는 연구(Connell, 1987)를 바탕으로 '새로운 의존형태소 일반화 과제(NBMG; Roseberry \& Connell, 1991)' 가 제작되었다. 새로운 의존형태소 일반화 과제(NBMG)는 '형태소 학습 능력'을 확인할 수 있는 과제로써, 단어 뒤에 새로운 의존형태소를 붙이면 다른 모양의 사물이 된다는 규칙을 학습하게 한 뒤, 아동이 규칙 일 반화를 할 수 있는지 확인하는 과제이다

Roseberry와 Connell (1991)에서 영어와 스페인어를 사용하는 만 4 세 5 개월에서 만 6 세 4 개월의 26 명의 이중언어 아동을 대상으 로 단어 뒤에 의존형태소/-ə/를 붙이면 사물 그림이 절반이 된다는 규칙을 학습시킨 뒤 일반화가 가능한지 알아보기 위해, 영어로 구 성된 새로운 의존형태소 일반화 과제(NBMG)를 시행하였다. 결과 적으로 일반 아동 13 명 중 12 명의 아동을 정상 아동으로 구분해 냈 으며, 1 명은 언어발달지연으로 구분하는 오류를 보였다. 또한 13 명 의 이중언어 언어발달지연 아동 중 10 명의 아동을 언어발달지연 아동으로 선별하였으나, 3 명의 아동을 정상으로 구분하는 오류가 보여 $85 \%$ 의 정확성을 보였다. 그러나 선별에 실패한 일반 아동 1 명 과 언어발달지연 아동 3 명에게 스페인어로 새로운 의존형태소 일 반화 과제(NBMG)를 수행하였다면, 보다 정확한 선별이 가능할 수 있었을 것이라는 아쉬움을 남겼다.

이러한 이유로, 다음 연구에서는 21 명의 학령 전기 베트남-영어 이중언어 일반 아동을 대상으로 영어와 베트남어로 제작된 새로운 의존형태소 일반화 과제(NBMG)를 제작하여 실험이 진행되었다 (Hwa-Froelich \& Matsuo, 2005). 영어 단어에 베트남어 의존형태 소를 붙여서 이중언어 아동이 의존형태소 규칙을 학습할 수 있는 지 평가하였고, 새로운 의존형태소 일반화 과제(NBMG) 점수와 수 용 및 표현 언어는 강한 정적 상관관계를 보였다. 비록 모국어와 제2 언어 모두를 사용하여 과제를 제작하였지만, 영어 단어와 베트남어 의존형태소의 조합으로 아동의 혼란을 가중시키는 문제가 있었다.

선행연구의 문제점을 해결하기 위해, 두 가지 언어(영어, 스페인 어)로 각각 구성된 새로운 의존형태소 일반화 과제(NBMG)가 제작 되었다(Kohnert \& Danahy, 2007). 만 3세 6개월에서 만 5세 8개월 의 스페인어-영어 이중언어 일반 아동 20 명을 두 집단으로 무작위 로 나눈 후, 한 집단에는 스페인어로 의존형태소 과제를 진행하였 고, 나머지 집단에는 영어로 구성된 의존형태소 과제를 시행하였 
다. 그 결과 모국어인 스페인어로 학습한 집단의 수행도가 현저하 게 높게 나타남으로써, 언어 기저 능력보다 언어 경험이 점수에 영 향을 미친다고 결론 내렸다. 그러나 Roseberry와 Connell (1991)의 연구에서 만 4 세 5 개월에서 만 6 세 4 개월의 아동을 대상으로 한 것 에 반해 Kohnert와 Danahy (2007)에서는 만 3세 6개월에서 만 5세 8 개월의 아동을 대상으로 했기 때문에, 영어 노출 시간이 1 년 미만 으로 충분하지 않았다는 점을 유념해야 한다. 더욱이, 대상자는 모 국어와 제2언어 중 한 가지 언어만으로 형태소 학습 능력이 평가되 었으므로, 두 가지 언어로 모두 과제를 시행한다면, 이 결과가 변경 될 가능성이 있었다.

한국어로 구성된 새로운 의존형태소 과제를 시행한 연구(Hong \& Yim, 2014)도 있다. 2년 이상 제2언어에 노출된 만 5세에서 만 7세 의 한국어-영어 이중언어 일반 아동 21 명과 이중언어 언어발달지연 아동 19 명을 대상으로 연구가 실시되었고, 한국어 새로운 의존형 태소 일반화 과제(KNBMG)의 민감도는 $47.4 \%$, 특이도는 $76.2 \%$ 로 판별하는 것이 가능하여, 이중언어 일반 아동과 이중언어 언어발 달지연 아동 간의 유의한 차이를 나타내는 것으로 나타났다. 그러나 한국어-영어 이중언어 아동의 언어를 평가하기 위해서, 한국어 형 태소 학습 능력만 평가한 것은 충분하지 않으며, 영어와 한국어 과 제를 모두 시행했다면 선별 결과가 보다 정확했을 것으로 예상된다. 이처럼 이중언어 아동의 언어를 정확히 평가하기 위해서는 아동 이 사용하는 두 가지 이상의 언어를 모두 사용하여 평가해야 하지 만(Kohnert, 2010), 선행연구들에서는 한 가지 언어로 제작된 새로 운 의존형태소 일반화 과제(NBMG)만을 사용하였기 때문에, 효과 적인 선별이 가능한지 판단할 수 없었다.

또한 선행연구들에서 이중언어 아동만을 대상으로 연구가 진행 되었다. 그러므로 상대적으로 한 가지 언어에 노출 빈도가 높은 단 일언어 아동 집단과 한 가지 언어에 노출 빈도가 낮은 이중언어 아 동의 형태소 학습 능력 수행력에 차이가 있는지 확인할 수 없었다. 이중언어 일반 아동의 새로운 의존형태소 일반화 과제(NBMG) 수 행력이 단일언어 일반 아동의 수행력 차이가 유의할 경우, 과제의
언어장애 선별 능력에 대해 의심해 볼 수 있으므로 단일언어 일반 아동의 과제 수행이 반드시 요구된다.

그러므로 이중언어 아동이 두 가지 언어로 제작된 새로운 의존 형태소 과제 $(\mathrm{NBMG})$ 를 시행하여, 언어 선별 과제로써 효과적인지 알아보고, 단일언어 아동의 과제 수행력과 비교해 보아야 할 것 이 다. 본 연구의 연구 질문은 다음과 같다.

1. 한국어 새로운 의존형태소 일반화 과제(Korean Novel BoundMorpheme Generalization, KNBMG) 점수가 한국어-영어 이 중언어 일반 아동, 한국어 단일언어 일반 아동, 한국어 단일언 어 언어발달지연 아동의 집단 간 차이가 유의 한가?

2. 한국어-영어 이중언어 일반 아동의 한국어 새로운 의존형태 소 일반화 과제(KNBMG) 점수, 영어 새로운 의존형태소 일반 화 과제(English Novel Bound-Morpheme Generalization, ENBMG) 점수, 한국어 수용어휘력(REVT) 원점수, 한국어 수용어휘력(REVT) 합산점수, 영어 수용어휘력(PPVT) 원점 수, 영어 수용어휘력(PPVT) 합산점수, 영어 노출 기간, 부모 보고서(ALDeQ) 간의 어떤 상관관계를 보이는가?

\section{연구 방법}

\section{연구 대상}

본 연구는 한국에 거주하는 만 4 세 6개월부터 만 7세 이중언어 일반 아동 30 명, 단일언어 일반 아동 30 명, 단일언어 언어발달지연 아동 20명을 대상으로 연구를 실시하였다(Table 1).

한국어-영어 이중언어 일반 아동 선정기준은 (1) 국내 또는 국외 에서 출생하여 모국어인 한국어를 습득하고 3 세 이후 영어를 습득 한 순차적 이중언어 아동으로서(McLaughlin, 1995), (2) 가정에서 형제, 부모 또는 부모 한 명과 고정적으로 한국어를 사용하며, (3) 영 어 전문 교육기관에 1년 이상 재학 중으로, (4) K-ABC 동작성 지능 (Moon \& Byun, 2003) 표준점수가 85이상이며, (5) 알버타 언어 및 발 달 설문지(Alberta Language and Development Questionnaire, AL-

Table 1. Participants' characteristics

\begin{tabular}{lcccccc}
\hline & Age $(\mathrm{mo})$ & Nonverbal IQ & REVT & REVT composite score $^{\text {a }}$ & PPVT & PPVT composite score $^{\text {a }}$ \\
\hline BINL & $72.23(11.53)$ & $114.4(9.18)$ & $62.33(19.33)$ & $79.80(17.26)$ & $62.33(19.33)$ & - \\
MNNL & $71.46(7.69)$ & $109.63(9.73)$ & $73.06(13.22)$ & - & - & - \\
MNLD & $71.91(9.35)$ & $108.05(11.72)$ & $50.05(10.59)$ & & - \\
\hline
\end{tabular}

Values are presented as mean (SD).

$\mathrm{BINL}=$ bilingual children with normal language; MNNL= monolingual children with normal language; $\mathrm{MNLD}=$ monolingual children with language delay; Nonverbal IO=Korean Kaufman Assessment Battery for Children (Moon \& Byun, 2003); REVT= Receptive \& Expressive Vocabulary Test (Kim, Hong, Kim, Jang, \& Lee, 2010); PPVT= Peabody Picture Vocabulary Test-4th edition (Dunn, \& Dunn, 2007).

${ }^{a}$ Composite score derived from Yim, Yoon, \& Lee (2016). 
DeQ; Paradis, Emmerzael, \& Duncan, 2010) 결과 0 SD 이상에 해당 되며, (6) 수용·표현 어휘력검사(Receptive and Expressive Vocabulary Test, REVT: Kim, Hong, Kim, Jang, \& Lee, 2009) 중 수용어휘력 검사 후 오반응한 문항을 영어로 시행한 합산점수(Yim, Yoon, et al., 2016)와 Peabody Picture Vocabulary Test-4th edition (PPVT-IV; Dunn \& Dunn, 2007) 시행 후 오반응한 문항을 한국어로 시행한 합 산 어휘력 점수 결과가 모두 - $1 \mathrm{SD}$ 이상에 속하며, (7) 신체, 감각, 정 서, 행동 등의 기질 문제를 동반하지 않은 아동을 대상으로 하였다.

한국어 단일언어 일반 아동 선정기준은 (1) 국내에서 출생하여 가정 및 교육기관에서 한국어를 유창하게 구사하며, (2) 교육기관 에서 영어를 학습하는 시간이 하루 최대 1 시간을 초과하지 않으며, (3) K-ABC 동작성 지능(Moon \& Byun, 2003) 표준점수가 85점 이 상이고, (4) 수용·표현 어휘력 검사(REVT; Kim et al., 2009)의 결과 에서 수용어휘력 점수가 -1 SD 이상에 속하며, (5) 신체, 감각, 정서, 행동 등의 기질적 문제를 동반하지 않은 아동을 대상으로 하였다.

한국어 단일언어 언어발달지연 아동 선정기준은 (1) 국내에서 출 생하여 가정 및 교육기관에서 한국어를 유창하게 구사하며, (2) 교 육기관에서 영어를 학습하는 시간이 하루 최대 1 시간을 초과하지 않고, (3) K-ABC 동작성 지능(Moon \& Byun, 2003) 표준점수가 85 점 이상이며, (4) 수용·표현 어휘력검사(REVT; Kim et al., 2009) 중 수용어휘력 점수가 - $1.25 \mathrm{SD}$ 미만에 속하고, (5) 신체, 감각, 정서, 행 동 등의 기질적 문제를 동반하지 않은 아동을 대상으로 하였다.

이중언어 일반 아동은 한국어 수용어휘력(REVT) 원점수를 산 출한 후 오반응한 문항은 영어로 질문하여 합산점수를 낸 한국어 수용어휘력(REVT) 합산점수를 산출하였으며, 영어 수용어휘력 (PPVT) 원점수에 오반응한 문항은 한국어로 질문하여 합산점수를 낸 영어 수용어휘력(PPVT) 합산점수를 산출하였다(Yim, Yoon, et al., 2016).

이중언어 일반 아동의 한국어 수용어휘력(REVT) 원점수는 62.33 $(\mathrm{SD}=19.33)$ 점이며, 한국어 수용어휘력(REVT) 합산점수는 79.8 $(\mathrm{SD}=17.26)$ 점이었다. 영어 수용어휘력(PPVT) 원점수는 $74.68(\mathrm{SD}$ $=24.39)$ 점이고, 영어 수용어휘력(PPVT) 원점수는 $102.13(\mathrm{SD}=$ 29.71)이었다. 이 결과는 Figure 1에 제시하였다.

이중언어 일반 아동의 평균 생활연령은 $72.23(\mathrm{SD}=11.53)$ 개월, 단일언어 일반 아동 평균 생활연령은 $71.46(\mathrm{SD}=7.69)$ 개월이었으 며, 단일언어 언어발달지연 아동의 평균 생활연령은 $71.91(\mathrm{SD}=9.35)$ 개월이다. 이중언어 일반 아동의 동작성 지능지수 평균은 114.4 $(\mathrm{SD}=9.18)$ 점이고, 단일언어 일반 아동 동작성 지능지수 평균은 $109.63(\mathrm{SD}=9.73)$ 점이며, 단일언어 언어발달지연 아동 동작성 지 능지수 평균은 $108.05(\mathrm{SD}=11.72)$ 점이다.

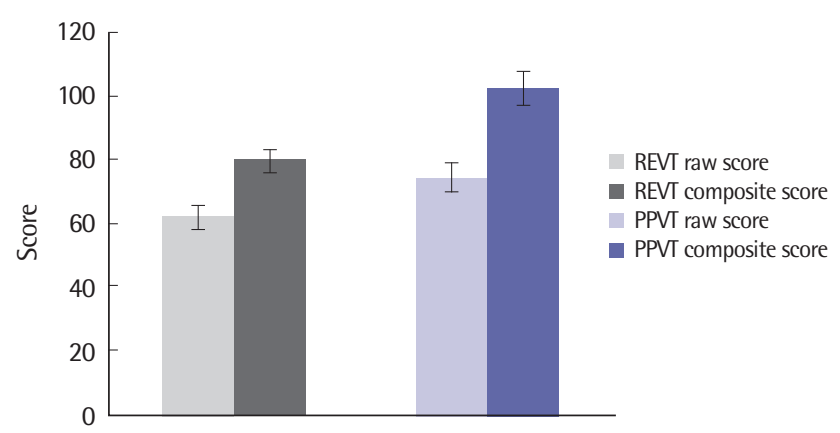

Figure 1. The raw scores and composite scores in REVT-R \& PPVT-R in bilingual with normal language. REVT-R=Receptive and Expressive Vocabulary Test-receptive (Kim, Hong, Kim, Jang, \& Lee, 2010); PPVT-R=Peabody Picture Vocabulary Test-receptive 4th edition (Dunn \& Dunn, 2007).

이중언어 일반 아동의 원점수는 $62.33(\mathrm{SD}=19.33)$ 점이고, 평균 한국어 수용어휘력(REVT) 합산점수는 $79.8(\mathrm{SD}=17.26)$ 점이다. 단일언어 일반 아동 평균 수용어휘력 점수는 $73.06(\mathrm{SD}=13.22)$ 점 이며, 단일언어 언어발달지연 아동의 평균 수용어휘력 점수는 50.05 $(\mathrm{SD}=10.59)$ 점이다.

집단의 통제가 잘 이루어졌는지 확인하기 위해 이중언어 일반 아 동, 단일언어 일반 아동, 단일언어 언어발달지연 아동의 생활연령, 동작성 지능지수, 한국어 수용어휘력을 일원분산분석(one way $\mathrm{ANOVA})$ 을 실시하였다. 분석결과, 세 집단 간 생활연령에서 유의 한 차이가 나지 않았고 $\left(F_{(2,77)}=.054, p>.05\right)$, 동작성 지능지수에서 도 차이가 유의하지 않았고 $\left(F_{(2,77)}=2.842, p>.05\right)$, 이중언어 일반 아동의 한국어 수용어휘력(REVT) 원점수, 한국어 수용어휘력(RE$\mathrm{VT}$ ) 합산점수, 단일언어 일반 아동의 한국어 수용어휘력(REVT) 원점수, 단일언어 언어발달지연 아동의 한국어 수용어휘력(REVT) 원점수에서 통계적으로 유의한 차이가 나타났다 $\left(F_{(3,106)}=14.934\right.$, $p<.001)$. 어떤 집단 비교에서 유의한 차이가 있는지 확인하기 위하 여, Bonferroni를 통한 사후검정을 실시한 결과, 단일언어 일반 아 동의 한국어 수용어휘력(REVT) 점수는 $71.46(\mathrm{SD}=7.69)$ 점, 이중 언어 일반 아동의 한국어 수용어휘력(REVT) 합산점수는 79.8 (SD $=17.26)$ 점으로 단일언어 언어발달지연 아동의 점수인 $50.05(\mathrm{SD}=$ 10.59)점보다 유의하게 높았으며, 단일언어 일반 아동과 이중언어 일반 아동의 점수 차이는 통계적으로 유의하지 않았다. 또한 이중 언어 일반 아동의 한국어 수용어휘력(REVT) 원점수는 $62.33(\mathrm{SD}=$ 19.33)점이고, 한국어 수용어휘력(REVT) 합산점수는 $79.8(\mathrm{SD}=17.26)$ 점으로 유의한 차이를 보였으나, 이중언어 일반 아동의 한국어 수 용어휘력(REVT) 원점수와 단일언어 언어발달지연 아동의 수용어 휘력(REVT) 원점수는 유의한 차이가 없었다. 한국어 수용어휘력 에 대한 결과는 Figure 2에 제시 하였다. 


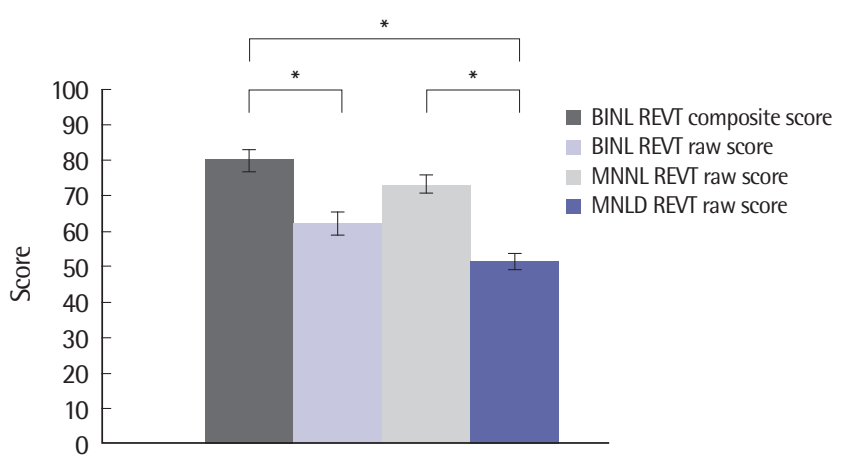

Figure 2. The raw scores and composite scores in REVT-R among groups. REVT$\mathrm{R}=$ Receptive and Expressive Vocabulary Test-receptive (Kim, Hong, Kim, Jang, \& Lee, 2010); BINL= bilingual with normal language; $M N L D=$ monolingual with normal language. ${ }^{*} p<.05$.

\section{연구 도구}

언어 평가 과제

표준화수용어휘력 검사도구와수용어휘력 합산점수

이중언어의 아동은 두 언어로 모든 것을 동시에 경험하는 것이 아니기 때문에 한 언어에 대한 평가는 이중언어 아동의 능력을 과 소평가하게 될 수 있다(Kayser, 1995; Langdon, 1992). 그러므로 본 연구에서는 기존에 사용하던 수용·표현 어휘력검사(REVT; Kim et al., 2009)와 PPVT-IV (Dunn \& Dunn, 2007)의 원점수와 함께 수용 어휘력 합산점수 방식(Hong \& Yim, 2014; Yim, Yoon, et al., 2016) 을 채택하여 평가하였다.

수용어휘력 합산점수 시행 방법은 다음과 같다. 검사도구의 평 가 언어로 1차 평가(REVT, 한국어; PPVT-IV, 영어)를 실시한 후, 평가 언어로 실시했을 때 오반응한 부분을 다른 언어로 재평가하 여 2차 평가(REVT, 영어; PPVT-IV, 한국어)를 진행한다. 기초선, 최고 한계선 그리고 점수 산출방식 모두 해당 검사의 방식에 따른 다. 이러한 합산점수 방식은 단어의 개념(concept) 이해 여부를 파 악하고, 이중언어 아동의 실제 어휘 크기(vocabulary size)를 파악 하기 위한 방법이다(Kohnert et al., 1998; Pearson et al., 1997; Pearson, 2007).

\section{부모보고 설문지}

알버타 언어발달 설문지(ALDeQ; Paradis et al., 2010)는 학령전 기 아동의 언어 및 발달을 부모의 설문조사 방식으로 알아보는 방 식이다. 알버타 언어발달 설문지는 영어를 학습하는 모든 아동에 게 실시할 수 있으며, 이중언어 아동을 대상으로 일반 아동과 언어 발달지연 아동을 선별할 수 있는 보충 검사로써 매우 효과적이다 (Restrepo, 1998). 설문지의 하위 영역은 초기 발달, 현재 모국어 능 력, 아동의 습관, 선호 활동, 가족력으로 구성되어 있으며, 아동이 연
구 과제를 시행하는 동안 주양육자가 총 30 분 이내로 답할 수 있다.

이 설문지는 선행연구(ALDeQ; Paradis et al., 2010)에서 내용타 당도가 검증 되었으며, 본 연구에서 사용한 설문지는 국내 선행연 구(Hong \& Yim, 2014)에서 사용한 번역본이다. 설문 문항이 끝난 후, 본 연구에 필요한 영어 전문 교육기관 입학 시기, 입학 전 언어 환경, 아동 언어발달에 대한 부모의 의견을 적을 수 있는 문항을 마 지막에 추가하였다.

연구 과제

새로운 의존형태소 일반화 과제(NBMG)

의존형태소란 자립성이 없고 다른 형태소에 의존해야만 쓰일 수 있는 형태소를 말한다. 본 과제는 이중언어 아동이 새로운 의존형 태소를 학습하고 일반화를 할 수 있는지 평가하기 위한 과제이다. 본 연구에서 제작한 새로운 의존형태소 일반화(NBMG) 과제는 Roseberry와 Connell (1991)의 연구와 Hong과 Yim (2014)의 연구 과제를 수정·응용하여 한국어 새로운 의존형태소 일반화 과제 (KNBMG)와 영어 새로운 의존형태소 일반화 과제(ENBMG)를 제 작하였다.

새로운 의존형태소 일반화 과제(NBMG) 제작: 새로운 의존형태 소 학습을 위한 한국어 선정 어휘는 36 개월 이전 아동의 표현 고빈 도 어휘 20개를 선정하였고(Lee, Chang-Song, Choi, \& Lee, 2009), 영어 어휘는 단어를 기준으로 역시 36 개월 이전 아동의 표현 고빈 도 어휘 20개를 선정하였다(Fenson et al., 1993). 사용되는 어휘는 모두 마지막 음절이 받침 또는 자음으로 끝나며, 한국어와 영어 각 각 1 음절 10 개, 2 음절 10 개로 총 20 개의 어휘를 선별하였다. 선정 어 휘목록은 Appendix 1에 추가하였다.

새로운 의존형태소 일반화 과제(NBMG) 대상자: 한국어 단일언 어 일반 아동과 한국어 단일언어 언어발달지연 아동에게는 한국 어로 제작한 한국어 의존형태소 일반화 과제(이하 한국어 형태소 과제)를 실시하고, 한국어-영어 이중언어 일반 아동에게는 한국어 의존형태소 일반화 과제(KNBMG)와 영어 의존형태소 일반과 과 제(이하 영어 형태소 과제)를 모두 실시한다.

이중언어 일반 아동 집단의 경우 무작위로 두 집단으로 나누어 한 집단은 한국어 형태소 과제(KNBMG)를 먼저 실시하였고, 다른 집단은 영어 형태소 과제(ENBMG)를 먼저 실시하였다.

한국어 형태소 과제(KNBMG)를 먼저 실시한 아동은 1 시간 뒤 영어 형태소 과제(ENBMG)를 실시하였으며, 마찬가지로 영어 형태 소 과제(ENBMG)를 먼저 실시한 아동은 1 시간 뒤 한국어 형태소 과제(KNBMG)를 실시하였다.

새로운 의존형태소 일반화과제(NBMG) 방법: 본 과제의 절차는 어 
휘확인 단계, 형태소 학습 단계, 일반화확인 단계로 3 단계로 나뉜다.

첫 번째 어휘 확인 단계는 선정 어휘로 제작한 그림을 보여주고, 모르는 어휘가 없도록 확인하는 단계이다. 연구자가 아동에게 다 음과 같은 지시문을 들려준다. "선생님이 그림을 그렸어. 이 그림이 뭐처럼 보이는지 말해 줄래?" (영어 과제 "I drew the drawings. What does this look like?”).

지시문을 들려준 후, 20 개의 어휘 그림 $(10 \mathrm{~cm} \times 9.5 \mathrm{~cm})$ 을 하나 씩 보여주며 아동이 단어의 이름을 말하도록 한다. 아동이 모르는 어휘가 있을 때는 다음과 같이 말한다. "이건 깃발이야. 따라 해볼 까?”(영어 과제 “This is a “bed'. Follow me ‘bed'.”)

아동에게 충분히 어휘를 숙지 시켜서 모르는 어휘가 없도록 하 되, 확인 단계에서 오반응 어휘가 5 개 이상이 되거나, 어휘 숙지가 되지 않으면 대상자에서 제외한다. 단, 기존에 알지 못했던 어휘가 아니라, 그림을 혼동할 경우 5 개 이상 오반응 하더라도 그림을 숙지 시킨 후 진행한다. 한국어 형태소 과제(KNBMG)시에는 한국어 지 시문을 읽어주고, 영어 형태소 과제(ENBMG)시에는 영어 지시문 을 읽어주되, 아동이 이해하지 못할 경우, 아동이 이해할 수 있는 언 어로 다시 설명한다. 어휘 확인 단계에서 보여주는 20 개의 그림은 형태소 학습 단계와 일반화 학습 단계에 사용된다.

두 번째 형태소 학습 단계는 어휘에 새로운 형태소를 붙여서 그 림이 변하는 규칙을 학습시키는 단계이다. 첫번째 어휘 확인 단계 에서 선정된 10 개의 어휘(1음절 5 개, 2 음절 5 개)에 형태소 규칙1과 형태소 규칙 2 를 적용한다. 한국어 형태소 규칙1은 /-웅/, 한국어 형 태소 규칙2는 /-오/, 영어 형태소 규칙1은/-2/, 영어 형태소 규칙2는 /-pl/이다. 예를 들어 선정 어휘 '곰'에 한국어 형태소 규칙1이 적용되 면 ‘곰/웅/'이 된다. 규칙이 포함된 어휘 목록은 Appendix 2에 제시 하였으며, 아동이 학습하게 되는 순서는 Appendix 3에 제시하였다

형태소 규칙이 어휘에 붙으면(예: 곰/웅/), 사물 그림도 변한다. 규 칙1이 적용되면 사물이 절반이 되고, 규칙2가 적용되면 사물이 작 아진다. 예를 들어 곰 그림이 절반이 되면 ‘곰/웅/이며, 신발 그림이 작아지면 '신발/오'가 된다. 어휘 그림에 규칙1이 적용된 그림은 Appendix 4에, 규칙2가 적용된 그림은 Appendix 5에 제시하였다.

한국어 형태소 과제(KNBMG)의 첫 번째 규칙인 /-웅/은 Hong 과 Yim (2014) 연구에서 사용한 파생 접미사/-웅/를 사용하였다. 파 생 접미사 /-웅/은 '집'과 '맞'의 어근에 접사 /-웅/을 붙여서 '지붕', '마중'을 생성하는데 사용된다. 그러나 이 규칙에서는 /-웅/을 새로 운 의존형태소로 제시하고, /-융/의 의미는 '사물의 반'으로 정의하 였다(Hong \& Yim, 2014). 예를 들어 어휘 '양말' 그림이 화면에 등 장한 후, 규칙1을 적용한 '양말/웅/'이 되면 양말 그림 반이 사라지 는 모습을 아동이 보게 된다. 지워지는 모습을 아동에게 제시하는
이유는 원본 그림에서 변경되었다는 것을 알리기 위함이다. 이러한 움직이는 과정은 파워 포인트(Power Point 2010)의 애니메이션 효 과를 통해 아동에게 제시된다.

한국어 형태소 과제(KNBMG)의 두 번째 규칙은 파생 접미사/오/이다. 파생 접미사/-오/는 '비롯하다', '돌다’에 접사/-오/를 붙여 서 '비로소, '도로'를 생성할 때 사용된다. 그러나 이 규칙에서는 /오/를 새로운 의존형태소로 제시하고, 그 의미는 '작아진 사물'을 말하는 것으로 새롭게 정의하였다. 어휘 '별' 에 규칙2가 적용되어 ‘별/오'가 되면 파워 포인트 애니메이션 효과를 통해 어휘 그림이 작아지는 모습을 보여준다.

영어 형태소 과제(ENBMG) 첫 번째 규칙은 Roseberry와 Connell (1991)의 연구에서 사용된 접미사/-ə/를 사용하였다. 접미사 /-ə/은 실제 존재하지 않은 형태소이며, 한국어 형태소 과제(KN$\mathrm{BMG})$ 와 같이 '사물의 반' 이라는 의미를 부여하였다.

영어 형태소 과제(ENBMG)의 두 번째 규칙은 선행연구를 응용 하여 접미사/-nl/을 선택하였다. 접미사/-nl/은 화학 작용이 일어났 음을 나타내는 접미사로써, 'ethane (에탄)', 'methane (메탄)'에 /-nl/ 을 붙여서 'ethanol (에탄올)'과 'methanol (메탄올)'을 만들 수 있 다. 그러나 일상생활에서 자주 사용되지 않은 접미사이며, 본 연구 에서는 ‘작아진 사물'을 말하는 것으로 새롭게 정의하였다.

한국어 형태소 과제(KNBMG)와 영어 형태소 과제(ENBMG)에 서 일상생활에 자주 사용되지 않으나, 존재하는 접미사 규칙(/-웅/, /-nl/, /-오/)과 실제 존재하지 않은 규칙(/-ə/)을 사용하였으며, 모든 규칙은 모음으로 시작하되, 한국어 형태소 과제(KNBMG)에서 규 칙1 (/-웅/)과 영어 형태소 과제(ENBMG)에서 규칙2 (/-pl/)는 받침 으로 끝나는 규칙을 사용하여 통일성을 주었다.

제시한 그림은 파워 포인트 애니메이션 효과를 적용하며, 원본 그림이 나타나고 연구자가 마우스를 움직이면 $1,500 \mathrm{~ms}$ 안에 그림 이 움직여서, 사물의 반이 사라지는 규칙1이 적용되거나, 사물이 작 아지는 규칙 2 가 된다. 사물이 반이 되는 규칙1은 선행연구들(HwaFroelich \& Matsuo, 2005; Hong \& Yim, 2014; Kohnert \& Danahy, 2007; Roseberry \& Connell, 1991)의 변경 규칙을 참고하였으며, 사 물이 작아지는 규칙2는 본 연구에서 난이도 조절을 위해 새로 추가 하였다. 언어 경험에 의한 결과를 최소화 하기 위해, 36 개월 이전 아 동의 표현 고빈도 어휘를 선정한 결과, 동물의 이름들이 선정되었 고, 동물 그림의 형체가 분리되거나 일그러지지 않으며 본래의 형체 를 유지하면서 변경하기 위해, 작아진 사물을 규칙 2 로 정의하였다.

형태소 학습 단계 시작 전, 연구자가 아동에게 말하는 지시문은 다음과 같다. "이제 컴퓨터 차례야. 컴퓨터가 그림 이름을 말해줄 거야. 잘 들어봐. 이따가 선생님이 물어볼 거야.”(영어 과제 “Now, it' 
s computer's turn. The computer will tell you the name of pictures. Listen carefully.")

아동에게 헤드폰을 씨운 후, 형태소 규칙이 포함된 그림을 파워 포인트로 보여준다. 어휘 그림 '곰' 이 제시되고, 규칙이 포함된 애니 메이션 효과(곰의 절반 그림)가 나타나면, 형태소 규칙이 포함된 어 휘를 알리는 문장(“이건 ‘곰/웅l' 이야.”) (영어과제 “This is a pen/ $\mathrm{bl} / . ”$ (녹음파일)이 녹음 파일로 재생되어, 아동이 형태소 규칙을 학습 할 수 있도록 한다. 한국어 녹음은 한국어가 모국어인 30대 여성에 의해 $80 \mathrm{~dB}$ 로 녹음 되었으며, 영어 녹음은 영어가 모국어인 30 대 여성에 의해 $80 \mathrm{~dB}$ 로 녹음되었다. 의존형태소가 적용된 단어 들은 연음규칙이 적용되지 않았다.

세 번째 단계는 형태소 일반화 단계이다. 형태소 일반화 단계에 서는 형태소 학습 단계에서 일반화가 되었는지 확인하는 단계이다. 지시문은 다음과 같다. "이제 너 차례야. 이 그림의 이름을 말해볼 까?”(영어과제 “Now it is your turn. Can you tell me the name of Pictures?”)

원본 그림이 처음에 등장한 후, 그림 이름이 녹음 파일을 통해 들 린다. "이건 꽃이야." (영어 과제 “This is a train.") (녹음 파일). 어 휘 이름이 들린 후, 학습 단계와 같은 방법으로 애니메이션 효과를 통해 규칙이 적용되고, 질문 녹음 파일이 들린다. “이건 뭘까?”(영 어과제 “What is this?") (녹음 파일)

총 10 개의 어휘를 확인하며 규칙1과 규칙 2 가 적용된 단어들이 아동에게 제시된다. 일반화 단계 확인 어휘 목록은 Appendix 6에 제시하였다.

\section{예비 실험}

본 실험을 시작하기 앞서 연구 과제인 새로운 의존형태소 일반화 과제(NBMG)의 예비 실험은 만 4 세 6개월부터 만 7세 아동, 37명을 대상으로 $1,2,3$ 차에 걸쳐 진행하였다. 예비실험을 통해 수정과 보 완을 하며 본 과제를 완성하였으므로, 1,2 차 예비실험을 진행한 과 제는 완성된 과제와차이가 있다.

1 차 예비실험에서 한국어 단일 일반 아동 5 명, 한국어-영어 이중 언어 일반 아동 5 명을 대상으로 어휘 그림 인식의 가능 여부, 형태 소 학습 여부를 확인하였다. 1 차 예비 실험결과 대상자의 $50 \%$ 가 '장갑'과 'melon' 그림을 보고 어휘를 확인할 수 없고, 형태소 학습 은 규칙 1 그림과 규칙2 그림을 3 개씩 번갈아 제시하며 학습하도록 한 결과, 일반화 단계에서 영어 형태소 과제(ENBMG)에서 정반응 률 $10 \%$, 한국어 형태소 과제(KNBMG)에서 정반응률이 $20 \%$ 로 형 태소 학습이 제대로 이루어지지 않은 것을 확인하였다. 1 차 형태소 학습 단계 목록과 순서는 Appendix 7에 제시하였다.
2차 예비실험 진행하기 앞서, '장갑'과 'melon' 그림을 수정하고, 형태소 학습 순서를 Appendix 3 와 같이 규칙 1 을 10 개 연속으로 학 습한 후, 규칙 2 를 10 개 연속으로 학습 한 것으로 변경하여, 한국어 단일언어 일반 아동 5 명, 한국어 단일언어 언어발달지연 아동 2 명 을 대상으로 한국어 형태소 과제 $(\mathrm{KNBMG})$ 를 실시하였고, 영어가 모국어인 영어-한국어 이중언어 일반 아동 10 명을 대상으로 영어 형태소 과제(ENBMG)를 실시하였다. 단일언어 일반 아동의 한국어 새로운 의존형태소 일반화 과제 $(\mathrm{KNBMG})$ 에서 평균 $6(\mathrm{SD}=1.41)$ 점으로 $65 \%$ 의 정반응률을 보였고, 영어-한국어 이중언어 일반 아 동의 영어 새로운 의존형태소 일반화 과제(ENBMG)에서 평균 6.7 $(\mathrm{SD}=3.77)$ 점으로 $67.4 \%$ 의 정반응률을 보였다.

3 차 예비 실험에서 정반응률을 높이기 위해, 형태소 학습 전 "이 따가 물어볼 거야. 그러니까 잘 봐야해. 알겠지?”(명시 구문)라는 구문을 포함하였고, 한국어 단일언어 일반 아동 10 명을 대상으로 한국어 형태소 과제 $(\mathrm{KNBMG})$ 를 실시한 결과 평균 $6.7(\mathrm{SD}=2.94)$ 점으로 나타났다.

$1,2,3$ 차에 걸쳐 진행한 예비실험을 통해 과제 수정 보완하였다.

\section{자료분석 및 결과처리}

부모보고 설문지를 제외한 모든 과제는 컴퓨터 화면에 제시하였 다. 모든 과제의 점수는 정반응을 1 점, 오반응을 0 점으로 하여 계산 하며, 부모보고 설문지와수용어휘력 점수는 원점수로 분석하였다.

새로운 의존형태소 일반화 과제(NBMG)는 이중언어 아동의 만 점은 20 점 기준이며, 단일언어 아동의 만점은 10 점 기준으로 하였 다. 컴퓨터와 헤드폰의 기술상의 문제로 인해 녹음 파일이 들리지 않거나, 화면이 움직이지 않은 문제가 발생했을 때에만 문제가 발 생한 시점부터 다시 시행하였다. 연음규칙은 적용한 아동과 적용하 지 않은 아동 모두 정반응 처리하였으며, 규칙을 비슷한 발음으로 대치했을 경우 정반응으로 하였고, 정반응률로 나타냈다.

한국어-영어 이중언어 일반 아동, 한국어 단일언어 일반 아동, 한 국어 단일언어 언어발달지연 아동 집단 간 한국어 새로운 의존형 태소 일반화 과제(KNBMG) 수행 차이를 확인하기 위해 일원혼합 분산분석(one-way ANOVA)을 실시한다. 또한 집단 내의 다양한 변인들(새로운 의존형태소 과제 합산점수, 수용어휘력, 영어 노출 시간, 부모 보고서 점수)를 살펴보고자 Pearson의 상관계수를 산 출한다.

\section{내용 타당도와 신뢰도}

새로운 의존형태소 일반화 과제(NBMG)의 적절성을 위해 1 급 언 어재활사 1 명, 2 급 언어재활사 5 명, 언어병리학과 대학원에 재학중 
인 대학원생 5명 대상으로 내용타당도에 대한 검증을 실시 하였다.

영어 새로운 의존형태소 일반화 과제(ENBMG)는 추가적으로 대학에서 영어영문학을 전공한 언어병리학과 대학원생 2 명, 모국 어를 영어로 사용하며 한국에서 TESOL학과 대학원에 재학중인 성인 2 명, 영어를 모국어로 하며 대학에서 영어학을 전공한 성인 1 명에게 추가적으로 실시하였다.

내용타당도(Lynn, 1986)는 1, 2차에 걸쳐 설문조사로 진행되었 으며, 설문 내용에는 과제에 사용된 형태소 규칙(한국어 2 개, 영어 2개), 형태소 규칙이 포함된 어휘 목록이 포함되었다. '매우 타당함' 4점, ‘타당함’ 3점, ‘타당하지 않음' 2점, '전혀 타당하지 않음' 1점과 같이 4 점 척도로 하였고, 2 점 이하의 경우 개선하여, 2 차 설문조사 를 진행하여 내용타당도를 검증하였다.

수용·표현 어휘력검사(REVT; Kim et al., 2009) 중 수용어휘력 검사와 PPVT-IV (Dunn \& Dunn, 2007), 마지막으로 새로운 의존 형태소 과제(NBMG)의 수행에 대한 평가자 간 신뢰도를 산출하기 위해 언어병리학과 대학원에 재학중인 2 명의 학생이 함께 산출하 였다. 신뢰도는 평자자 간 일치한 문항수를 전체 문항수로 나눈 후 100 을 곱하였고, 분석 결과 평자자 간 신뢰도는 $97 \%$ 였다.

\section{연구 결과}

\section{집단 간 한국어 새로운 형태소 일반화 학습 과제(KNBMG) 의 수행 차이}

이중언어 일반 아동, 단일언어 일반 아동과 단일언어 언어발달지 연 아동 집단의 한국어 새로운 형태소 일반화 과제에 대한 정반응 률의 평균 및 표준편차에 대한 기술통계는 Table 2 와 같다.

한국어 새로운 형태소 일반화 과제(KNBMG) 정반응률에서 이 중언어 일반 아동은 $52.3 \%(\mathrm{SD}=39.5 \%)$, 단일언어 일반 아동은 $60 \%(\mathrm{SD}=27 \%)$ 단일언어 언어발달지연 아동은 $20 \%(\mathrm{SD}=36.4 \%)$ 으로 나타났다.

세 집단의 한국어 새로운 형태소 일반화 과제(KNBMG)에 대한 정반응률이 통계적으로 유의하는지 확인하기 위하여 일원혼합분

Table 2. Descriptive statistics

\begin{tabular}{lc}
\hline & KNBMG Accuracy $(\%)$ \\
\hline BINL(N=30) & $52.3(39.5)$ \\
$M N N L(N=30)$ & $60.0(27.0)$ \\
$M N L D(N=20)$ & $20.0(36.4)$ \\
\hline
\end{tabular}

Values are presented as mean (SD).

KNBMG = Korean Novel Bound-Morpheme Generalization Task; BINL= bilingual with normal language; $\mathrm{MNNL}=$ monolingual with normal language; $\mathrm{MNLD}=$ monolingual with language delay. 석(one-way ANOVA)를 실시한 분석 결과, 집단에 대한 주효과가 통계적으로 유의하였다 $\left(F_{(2,77)}=9.312, p<.001\right)$. 어떤 집단 간 비교 에서 유의한 차이를 보이는지 확인하기 위하여 Bonferroni를 통한 사후검정을 실시한 결과, 이중언어 일반 아동의 한국어 형태소 과 제(KNBMG) 정반응률 $52.3 \%(\mathrm{SD}=39.5 \%)$ 와 단일언어 언어발달 지연 아동의 한국어 형태소 과제(KNBMG) 정반응률 $20 \%$ (SD = $36.4 \%)$ 보다 유의하게 높았고, 단일언어 일반 아동의 한국어 형태 소 과제 $(\mathrm{KNBMG})$ 정반응률 $60 \%(\mathrm{SD}=27 \%)$ 도 단일언어 언어발달 지연 아동의 한국어 형태소 과제(KNBMG) 정반응률보다 유의하 게 높았다. 반면에 이중언어 일반 아동의 정반응률과 단일언어 일 반 아동의 정반응률에 대해서는 차이가 통계적으로 유의하지 않 았다. 결과는 Figure 3 에 제시하였다.

\section{한국어-영어 이중언어 일반 아동의 한국어 새로운 형태소 일반화 과제(KNBMG) 점수, 영어 새로운 형태소 일반화 과제(ENBMG) 점수, 한국어 및 영어 수용어휘력, 변인들 간의 상관관계}

이중언어 일반 아동의 한국어 새로운 형태소 일반화 과제 $(\mathrm{KN}-$ $\mathrm{BMG}$ ) 점수, 영어 새로운 형태소 일반화 과제(ENBMG) 점수, 한국 어 수용어휘력(REVT) 원점수, 한국어 수용어휘력(REVT) 합산점 수, 영어 수용어휘력(PPVT) 원점수, 영어 수용어휘력(PPVT) 합산 점수, 영어 노출 기간, 부모 보고서 간의 상관관계를 확인하기 위해 Pearson 상관계수를 산출하였다. 그 결과는 Table 3과 같다.

한국어 형태소 과제(KNBMG)는 한국어 수용어휘력(REVT) 합 산점수 $(r=.420, p<.05)$, 영어 형태소 과제(ENBMG) $(r=.795, p<.01)$ 점수와 유의한 상관관계를 보였다. 한국어 수용어휘력(REVT) 합 산점수는 한국어 수용어휘력(REVT) 원점수 $(r=.728, p<.01)$, 영 어 수용어휘력(PPVT) 원점수 $(r=.423, p<.05)$, 영어 수용어휘력 (PPVT) 합산점수 $(r=.661, p<.01)$ 와 유의한 상관관계를 나타냈으

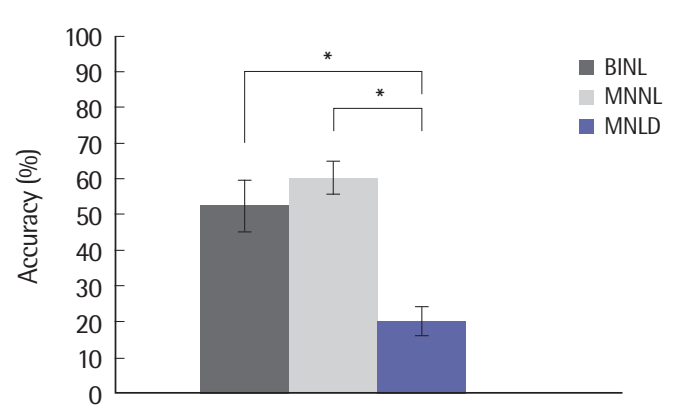

Figure 3. Korean Novel Bound-Morpheme Generalization Task accuracy among groups. BINL=bilingual with normal language; $\mathrm{MNNL}=$ monolingual with normal language; $\mathrm{MNLD}=$ monolingual with language delay. ${ }^{*} p<.05$. 
Yeonjoo Jo, et al. • Dynamic Assessment in Bilingual Children

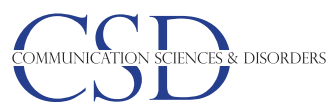

Table 3. Correlation coefficient among tasks in Bilingual children with normal language

\begin{tabular}{|c|c|c|c|c|c|c|c|}
\hline & KNBMG & ENBMG & REVT raw score & REVT composite ${ }^{\mathrm{a}}$ & PPVT raw score & PPVT composite ${ }^{\mathrm{a}}$ & Parent report \\
\hline ENBMG & $.795^{* *}$ & & & & & & \\
\hline REVT raw score & .328 & .310 & & & & & \\
\hline REVT composite ${ }^{a}$ & $.420^{*}$ & .217 & $.728^{* *}$ & & & & \\
\hline PPVT raw score & .242 & .178 & .253 & $.423^{* *}$ & & & \\
\hline PPVT composite ${ }^{b}$ & .318 & .200 & $.619^{* *}$ & $.661^{* *}$ & $.530^{* *}$ & & \\
\hline Parent report ${ }^{c}$ & -.045 & .171 & .286 & .076 & -.006 & .263 & \\
\hline English exposure & -2.02 & -259 & -0.75 & .070 & $.581^{* *}$ & .115 & -.139 \\
\hline
\end{tabular}

KNBMG = Korean Novel Bound-Morpheme Generalization Task; ENBMG= English Novel Bound-Morpheme Generalization Task; REVT=Receptive and Expressive Vocabulary Test (Kim, Hong, Kim, Jang, \& Lee, 2010); PPVT=Peabody Picture Vocabulary Test 4th edition (Dunn \& Dunn, 2007).

a,bomposite score derived from Yim, Yoon, \& Lee (2016) and 'parent report from Alberta Language and Development Questionnaire (Paradis, Emmerzael, \& Duncan, 2010). ${ }^{*} p<.05,{ }^{* *} p<.01$.

며, 영어 수용어휘력(PPVT) 합산점수는 한국어 수용어휘력(REVT) 원점수 $(r=.619, p<.01)$, 영어 수용어휘력(PPVT) 원점수 $(r=.530$, $p<.01)$ 와 유의한 상관관계를 보였다. 영어 노출 기간은 영어 수용 어휘력(PPVT) 합산점수 $(r=.581, p<.01)$ 와상관관계가 유의하였다.

\section{논의 및 결론}

본 연구는 한국어-영어 이중언어 일반 아동과 한국어 단일언어 일반 아동 및 단일언어 언어발달지연 아동을 대상으로 새로운 의 존형태소 일반화 학습과제(NBMG)의 수행 능력을 살펴보고자 하 였으며 결과는 다음과 같다.

첫째, 단일언어 언어발달지연 아동의 한국어 형태소 과제 $(\mathrm{KN}-$ $\mathrm{BMG}$ ) 수행은 이중언어 일반 아동과 단일언어 일반 아동에 비해 통 계적으로 유의미하게 낮았다. 즉, 언어발달지연 아동은 이중언어 일반 아동과 단일언어 일반 아동보다 한국어 형태소 과제(KNBMG) 점수에서 낮은 수행력을 보여 새로운 형태소 학습 능력에서도 결함 을 갖는 것으로 나타났다.

이 결과는 새로운 형태소 일반화 과제(NBMG)에서 이중언어 언 어발달지연 아동이 이중언어 일반 아동보다 낮은 수행력을 보인다 는 선행연구(Connell \& Stone, 1992; Hwa-Froelich \& Matsuo, 2005; Restrepo, 1998; Roseberry \& Connell, 1991)와 같은 결과라고 할 수 있으며, 언어발달지체 아동이 형태소 학습에서 어려움을 보인 다는 선행연구들(Connell, 1987; Restrepo, 1998)을 지지해주는 결 과이다.

Kohnert와 Danahy (2007)의 연구는 형태소 학습 능력은 언어발 달 기제가 아닌 이중언어 아동의 언어 경험에 따른다고 하였으나, 언어 환경이 다른 이중언어 일반 아동과 단일언어 일반 아동 사이 에 유의한 차이가 없었으므로, 언어 경험이 아닌 언어발달 기제에 따른다고 할 수 있다. 즉, 이중언어 아동이 새로운 의존형태소 일반
화 학습과제(NBMG)에서 낮은 수행력을 보였다면, 언어발달지연 을 의심해 볼 수 있다고 판단된다.

그러나 한국어 형태소 과제 $(\mathrm{KNBMG})$ 정반응률에서 이중언어 일반 아동은 $52.3 \%(\mathrm{SD}=39.5 \%)$, 단일언어 일반 아동은 $60 \%(\mathrm{SD}=$ $27 \%)$ 단일언어 언어발달지연 아동은 $20 \%(\mathrm{SD}=36.4 \%)$ 로, 이중언 어 일반 아동이 단일언어 일반 아동보다 낮은 수행력을 보였다. 이 중언어 일반 아동과 이중언어 언어발달지연 아동에게 한국어 형태 소 과제(KNBMG)와 영어 형태소 과제(ENBMG)를 모두 실시한다 면, 이중언어 일반 아동의 한국어 형태소 과제(NBMG) 점수에 관 하여 보다 풍부한 해석을 얻을 수 있을 것이며, 언어 능력 평가에 있 어서도 더욱더 정확한 결과를 얻을 수 있었을 것으로 예상된다.

본 연구와 마찬가지로 스페인어-영어 이중언어 아동을 대상으로 한 선행연구들(Kohnert \& Danahy, 2007; Roseberry \& Connell, 1991)에서도 스페인어와 영어 과제 모두를 실시하지 않았다는 한계 점으로 지목된 바 있으며, 추후 연구에서는 이중언어 언어발달지 연 아동 집단을 포함하여 한국어 형태소 과제(KNBMG)와 영어 형 태소 과제(ENBMG)을 모두 시행해야 할 것이다.

그러나 이러한 해석에 앞서, 선행연구들(Kohnert \& Danahy, 2007; Roseberry \& Connell, 1991)은 상대적으로 언어의 유사도가 높은 영어와 스페인어로 과제가 제작된 것에 반해, 본 연구는 한국 어로 과제를 제작했으므로 언어 간의 차이에 따른 한계성에 유념해 야한다.

본 연구에서 과제 제작 시 영어와 한국어의 상대적인 언어적 차 이가 결과에 영향을 미치는 것을 최소화 하기 위해, 영어 형태소 과 제(ENBMG)와 한국어 형태소 과제(KNBMG)의 선정 어휘의 발달 시기와 음절 수를 맞추어 선정하였으며, 형태소 결합 시 본 어휘의 변화를 최소화하기 위하여 자음 또는 받침으로 끝나는 어휘만을 선정하였고, 형태소 규칙(/-웅/, /-오/, /-nl/, /-2/)은 실제로 존재하지 않거나, 빈도가 높지 않은 의존형태소를 사용하였으며, 모두 모음 
으로 통일하였다.

그러나 본 연구에서 사용한 의존형태소(bound morpheme) 중 파생형태소(derivational morpheme)는 영어 인식 능력에 매우 중 요한 역할을 하고 있어(Koda, 2008; Koda \& Zehler, 2008; Ku \& Anderson, 2003; Kuo \& Anderson, 2006), 한국어의 파생형태소 보 다 상대적으로 인식이 빠르다. 또한 한국어 형태소 과제(KNBMG) 의 규칙으로 사용된 접미사/-웅/과/-오/는 학령기발달 문법형태소 이므로 언어적 차이점이 과제 결과에 영향을 미칠 수도 있다는 점 을 유념하여 해석해야 한다.

이에 따라 새로운 의존형태소 일반화 과제(NBMG)가 보다 신뢰 있는 선별과제가 되기 위해서는, 형태소 인식 능력(morphological awareness)을 비롯한 다양한 연구가 이루어져야 할 것으로 생각된다.

둘째, 이중언어 일반 아동의 한국어 새로운 의존형태소 일반화 과제(KNBMG) 점수, 영어 새로운 의존형태소 일반화 과제(EN$\mathrm{BMG}$ ) 점수, 한국어 수용어휘력(REVT) 원점수, 한국어 수용어휘 력(REVT) 합산점수, 영어 수용어휘력(PPVT) 원점수, 영어 수용어 휘력(PPVT) 합산점수, 영어 노출 기간, 부모 보고서 간의 어떠한 상 관관계가 있는지 확인한 결과, 이중언어 일반 아동의 한국어 형태 소 과제(KNBMG) 점수는 한국어 수용어휘력(REVT) 합산점수와 유의한 상관관계를 보였고, 한국어 형태소 과제(KNBMG) 점수와 영어 형태소 과제(ENBMG) 점수도 유의한 상관관계를 나타냈다. 또한 한국어 수용어휘력(REVT) 합산점수는 한국어 수용어휘력 (REVT) 원점수, 영어 수용어휘력(PPVT) 원점수, 영어 수용어휘력 (PPVT) 합산점수와 유의한 상관관계를 보였고, 영어 수용어휘력 (PPVT) 합산점수는 한국어 수용어휘력(REVT) 원점수, 영어 수용 어휘력(PPVT) 원점수와 유의한 상관관계를 보였고, 영어 노출 기 간은 영어 수용어휘력(PPVT) 합산점수와 유의한 상관을 보였다.

한국어 형태소 과제(KNBMG)는 한국어 수용어휘력(REVT) 합 산점수와 상관관계가 있다는 결과는 언어의 기저 능력을 나타내는 인지 처리 과제(cognitive processing tasks)가 이중언어 아동의 언 어의 어려움을 설명할 수 있다는 선행연구들(Kohnert et al., 2006; Windsor \& Kohnert, 2004; Windsor, Kohnert, Lobitz, \& Pham 2010)과 언어발달지연 아동에게 형태소 인식과 학습 능력에 한계 를 보인다는 연구들(Connell, 1987; Jacobson \& Schwartz, 2005)과 같은 결과를 보였으며, 새로운 형태소 일반화 과제(NBMG)에서 언 어발달지연 아동이 일반 아동보다 낮은 수행력을 보인다는 선행연 구(Connell \& Stone, 1992; Hwa-Froelich \& Matsuo, 2005; Restrepo, 1998; Roseberry \& Connell, 1991)와도 결과가 일치 한다.

또한 이중언어 일반 아동의 한국어 형태소 과제(KNBMG)는 한 국어 수용어휘력(REVT) 원점수와 상관관계를 보이지 않았으나,
한국어 수용어휘력(REVT) 합산점수와 유의미한 상관관계를 보였 다는 것에 의미가 있다. 한국어 수용어휘력(REVT) 합산점수는 이 중언어 집단이 수용어휘력(REVT)을 한국어로 측정한 후 오반응 한 항목을 영어로 실시한 후 합산점수를 산출하는 방식으로, 원점 수 보다 $62.33(\mathrm{SD}=19.33)$ 점, 합산점수가 $79.8(\mathrm{SD}=17.26)$ 점 높았 다. 일원분산분석(one-way ANOVA)를 통해 집단 간 수용어휘력 을 비교한 결과, 이중언어 아동의 수용어휘력(REVT) 원점수와수 용어휘력(REVT) 합산점수는 유의한 차이가 있으며, 이중언어 아 동의 수용어휘력(REVT) 원점수는 단일언어 일반 아동의 수용어 휘력(REVT) 점수와 유의한 차이가 나지 않았고, 단일언어 언어발 달지연 아동의 수용어휘력(REVT) 점수와도 유의한 차이도 나지 않았다. 본 결과는 Figure 2에 제시하였다.

그러므로 한국어-영어 이중언어 아동들이 합산점수가 아닌 기 존의 방식대로 한국어 원점수만 산출하였다면, 단일언어 일반 아 동과 언어발달지연 아동의 수용어휘력(REVT) 점수 사이에 위치 하여, 언어발달지연 아동으로 잘못 판단될 수도 있었다. 이는 이중 언어 아동의 언어평가를 위해서 아동이 사용하는 언어를 모두 평 가해야 하며, 이를 위한 새로운 점수 산출 방법이 필요하다는 선행 연구(Core, Hoff, Rumiche, \& Señor, 2013; Yim, Yoon, et al., 2016) 와 일치한다.

한국어 수용어휘력(REVT) 합산점수가 한국어 형태소 과제 (KNBMG)와 상관관계를 보이므로, 새로운 의존형태소 일반화 과 제(NBMG)가 이중언어 아동들을 위한 언어 선별 과제로 효과적인 과제가 될 수 있는 가능성이 있다고 보여진다. 언어재활사가 이중언 어 아동의 언어 평가 시 가장 어려운 점은, 언어재활사가 이중언어 아동이 사용하는 두 가지 이상의 언어를 모두 할 수 없을 때이다 (Kohnert, 2010). 그러나 이중언어 아동이 사용하는 한 가지 언어로 만 평가를 한다면, 언어장애가 있는 것으로 오진될 수 있으므로, 언 어재활사와 이중언어 아동이 공유하는 한 가지 언어로 제작된 새 로운 의존형태소 일반화 과제(NBMG)를 실시한다면, 아동의 언어 능력을 가늠해 볼 수 있을 것이라고 생각한다.

또한 한국어 형태소 과제(KNBMG)는 영어 형태소 과제(ENBMG) 와도 상관관계를 보였다.

본 연구 대상자들의 모국어와 사회 언어는 모두 한국어이지만, 한 국어 형태소 과제(KNBMG) 점수와 영어 형태소 과제(ENBMG) 점 수는 상관관계를 나타냄으로써, 새로운 의존형태소 일반화 과제 (NBMG)가 언어 경험이 아닌 언어발달 기제의 능력을 평가한다는 선행연구(Connell \& Stone, 1992; Hwa-Froelich \& Matsuo, 2005; Restrepo, 1998; Roseberry \& Connell, 1991)를 지지하는 결론을 보였다. 한편, 모국어가 아닌 제 2 언어의 형태소 일반화 과제(NBMG)는 
아동의 언어 능력을 설명할 수 없으며, 언어기제가 아닌 언어 경험 에 영향력을 받는다는 선행연구(Kohnert \& Danahy, 2007)와는 다 른 결론을 보였지만, 수용어휘력(REVT) 합산점수와 영어 형태소 과제(ENBMG)는 유의미한 상관관계가 없고, 한국어 형태소 과제 (KNBMG)만이 유의미한 상관관계가 있다는 결과로 보아, 아동의 모국어로 제작된 새로운 의존형태소 일반화 과제(NBMG)가 이중 언어 능력을 더욱더 잘 설명할 수 있다는 점에서는 선행연구(Kohnert \& Danahy, 2007)와는 같은 결론을 보였다.

그러나 선행연구(Kohnert \& Danahy, 2007; Roseberry \& Connell, 1991)의 모국어인 스페인어는 소수 언어이며, 제 2 언어인 영어 가 다수언어인 반면, 본 연구의 한국어-이중언어 아동은 모국어인 한국어가 다수 언어이고 제 2 언어는 제한된 교육기관에서만 사용 된다는 점을 고려해 볼 때, 언어 경험과 환경을 완전히 배제할 수 없 을 것으로 판단된다.

한국어 수용어휘력(REVT) 합산점수는 한국어 수용어휘력(RE$\mathrm{VT}$ ) 원점수, 영어 수용어휘력(PPVT) 원점수, 영어 수용어휘력(PP$\mathrm{VT}$ ) 합산점수와유의한 상관관계를 보였고, 영어 수용어휘력(PPVT) 합산점수는 한국어 수용어휘력(REVT) 원점수, 영어 수용어휘력 (PPVT) 원점수와 유의한 상관관계를 보였고, 영어 노출 기간은 영 어 수용어휘력(PPVT) 합산점수와 유의한 상관을 보였다.

한국어 수용어휘력(REVT) 합산점수는 한국어로 원점수를 산 출한 뒤, 오반응한 문항에 영어로 질문하여 다시 채점하는 방식이 므로, 한국어 수용어휘력(REVT) 원점수가 높을 경우 합산점수도 높아지면서 유의한 상관관계가 나타나는 것으로 보여 진다. 또한 한국어 수용어휘력(REVT) 합산점수는 한국어로 오반응했을 시, 영어로 다시 진행하기 때문에 한국어 수용어휘력(REVT) 합산점 수는 한국어만 포함된 점수가 아니다. 그러므로 영어만 시행하는 영어 수용어휘력(PPVT) 원점수와 한국어 수용어휘력(REVT) 합 산점수는 유의미한 상관관계를 보이며, 영어로 시행한 뒤 오반응한 항목을 한국어로 시행하는 영어 수용어휘력(PPVT) 합산점수와 한국어 수용어휘력(REVT) 합산점수도 유의한 상관관계를 나타 내는 것으로 여겨진다.

영어 수용어휘력(PPVT) 합산점수가 한국어 수용어휘력(REVT) 원점수, 영어 수용어휘력(PPVT) 원점수와 유의한 상관관계를 보 이는 이유도 이와 같이 영어 수용어휘력(PPVT) 합산점수에 영어 와 한국어가 모두 평가되며, 영어 수용어휘력(PPVT) 원점수를 기 반으로 합산점수가 측정되기 때문이라고 보인다. 또한 영어 노출 기 간은 영어 전문 교육기관에 재학한 기간을 의미하므로, 높은 영어 노출 기간이 영어 수용어휘력(PPVT) 합산점수를 높인 것으로 예 측된다.
결론적으로 새로운 의존형태소 일반화 학습과제(NBMG)는 이 중언어 아동의 언어 기저능력을 평가할 수 있는 선별 과제로써 유 용하므로, 새로운 의존형태소 일반화 과제(REVT)에서 낮은 수행 력이 나타날 경우, 아동의 언어 능력과 상관이 있을 것으로 판단할 수 있을 것이다. 또한, 정확한 이중언어 아동의 정확한 언어 평가를 위해서 아동이 사용하는 두 가지 이상의 언어를 모두 사용하여 하 지만, 두 가지 언어를 모두 사용할 수 없을 때는 언어 재활사와 아동 이 공유하는 한 가지 언어로 새로운 의존형태소 일반화 과제(NBMG) 를 제작하여, 아동의 언어 능력을 가늠해 볼 수 있을 것이라고 판단 된다.

그러나 본 연구에서 이중언어 언어발달지연 아동 집단이 포함되 지 않아, 이중언어 일반 아동과의 한국어 형태소 과제(KNBMG)와 영어 형태소 과제(ENBMG) 수행을 비교하여 살펴 볼 수 없었다는 한계점이 있다. 또한 영어와 한국어의 언어적 차이가 새로운 의존 형태소 일반화 과제(NBMG) 결과에 영향을 줄 수 있으므로, 해석 에 유의해야 하며, 앞으로 이중언어 아동을 대상으로 다양한 형태 소 인식 및 학습 능력에 대한 추후 연구가 필요할 것으로 생각된다.

\section{REFERENCES}

Anderson, R. T. (2001). Learning an invented inflectional morpheme in Spanish by children with typical language skills and with specific language impairment (SLI). International Journal of Language \& Communication Disorders, 36, 1-19.

Apel, K., Diehm, E., \& Apel, L. (2013). Using multiple measures of morphological awareness to assess its relation to reading. Topics in Language Disorders, 33, 42-56.

Archibald, L. M., \& Gathercole, S. E. (2006). Short-term and working memory in specific language impairment. International Journal of Language \& Communication Disorders, 41, 675-693.

Baddeley, A. D., \& Hitch, G. (1974). Working memory. The Psychology of Learning and Motivation, 8, 47-89.

Bialystok, E. (2001). Bilingualism in development: language, literacy, and cognition. Cambridge: Cambridge University Press.

Bloomfield, L. (1933). Language. Chicago: University of Chicago Press.

Briscoe, J., Bishop, D. V., \& Norbury, C. F. (2001). Phonological processing, language, and literacy: a comparison of children with mild-to-moderate sensorineural hearing loss and those with specific language impairment. Journal of Child Psychology and Psychiatry, 42, 329-340.

Caesar, L. G., \& Kohler, P. D. (2007). The state of school-based bilingual as- 
sessment: actual practice versus recommended guidelines. Language, Speech, and Hearing Services in Schools, 38, 190-200.

Caplan, D., \& Waters, G. S. (1999). Verbal working memory and sentence comprehension. Behavioral and Brain Sciences, 22, 77-94.

Connell, P. (1987). An effect of modeling and imitation teaching procedures on children with and without specific language impairment. Journal of Speech, Language, and Hearing Research, 30, 105-113.

Connell, P. J., \& Stone, C. A. (1992). Morpheme learning of children with specific language impairment under controlled instructional conditions. Journal of Speech, Language, and Hearing Research, 35, 844-852.

Core, C., Hoff, E., Rumiche, R., \& Señor, M. (2013). Total and conceptual vocabulary in Spanish-English bilinguals from 22 to 30 months: implications for assessment. Journal of Speech, Language, and Hearing Research, 56, 16371649 .

Dollaghan, C. A. (1987). Fast mapping in normal and language-impaired children. Journal of Speech and Hearing Disorders, 52, 218-222.

Dollaghan, C., \& Campbell, T. F. (1998). Nonword repetition and child language impairment. Journal of Speech, Language, and Hearing Research, 41, 1136-1146.

Dunn, D. M., \& Dunn, L. M. (2007). Peabody Picture Vocabulary Test Fourth Edition. San Antonio, TX: Pearson.

Eadie, P. A., Fey, M. E., Douglas, J. M., \& Parsons, C. L. (2002). Profiles of grammatical morphology and sentence imitation in children with specific language impairment and Down syndrome. Journal of Speech, Language, and Hearing Research, 45, 720-732.

Evans, J. L., Saffran, J. R., \& Robe-Torres, K. (2009). Statistical learning in children with specific language impairment. Journal of Speech, Language, and Hearing Research, 52, 321-335.

Fenson, L., Dale, P., Reznick, J. S., Thal, D., Bates, E., Hartung, J., ... \& Reilly, J. (1993). Macarthur communicative development inventories: user's guide and technical manual. San Diego, CA: Singular Publishing Group.

Gathercole, S. E., \& Baddeley, A. D. (1990). Phonological memory deficits in language disordered children: is there a causal connection? Journal of Memory and Language, 29, 336-360.

Gathercole, S. E., \& Pickering, S. J. (2000). Working memory deficits in children with low achievements in the national curriculum at 7 years of age. British Journal of Educational Psychology, 70, 177-194.

Genesee, F., Paradis, J., \& Crago, M. B. (2004). Dual language development \& disorders: a handbook on bilingualism \& second language learning. Baltimore, MD: Paul H. Brookes Publishing.
Gutiérrez-Clellen, V. F., \& Simon-Cereijido, G. (2010). Using nonword repetition tasks for the identification of language impairment in Spanish-English-Speaking children: does the language of assessment matter? Learning Disabilities Research \& Practice, 25, 48-58.

Hakuta, K. (1986). Mirror of language: the debate on bilingualism. New York, NY: Basic Books.

Hong, S., \& Yim, D. (2014). The assessment of language impairment in bilingual children through learning and memory tasks. Communication Sciences \& Disorders, 19, 31-44.

Hwa-Froelich, D. A., \& Matsuo, H. (2005). Vietnamese children and languagebased processing tasks. Language, Speech, and Hearing Services in Schools, $36,230-243$.

Jacobson, P. F., \& Schwartz, R. G. (2005). English past tense use in bilingual children with language impairment. American Journal of Speech-Language Pathology, 14, 313-323.

Kayser, H. (1995). Bilingual speech language pathology: an Hispanic focus. Clifton Park, NY: Delmar, Cengage Learning.

Kemper, R. L., \& Vernooy, A. R. (1993). Metalinguistic awareness in first graders: a qualitative perspective. Journal of Psycholinguistic Research, 22, 4157.

Kim, Y. T., Hong, G. H., Kim, K. H., Jang, H. S., \& Lee, J. Y. (2009). Receptive \& expressive vocabulary test (REVT). Seoul: Seoul Community Rehabilitation Center.

Koda, K. (2005). Learning to read across writing systems: transfer, metalinguistic awareness, and second language reading development. In V. Cook \& B. Bassetti (Eds.), Second language writing systems (pp. 311-334). Tonawanda, NY: Multilingual Matters.

Koda, K., \& Zehler, A. M. (2008). Introduction. Conceptualizing reading universals, cross-linguistic variations, and second language literacy development. In K. Koda \& A. M. Zehler (Eds.), Learning to read across languages: cross-linguistic relationships in first-and second-language literacy development (pp. 1-9). New York, NY: Routledge.

Kohnert, K. (2008). Language disorders in bilingual children and adults. San Diego, CA: Plural Publishing.

Kohnert, K. (2010). Bilingual children with primary language impairment: issues, evidence and implications for clinical actions. Journal of Communication Disorders, 43, 456-473.

Kohnert, K. J., Hernandez, A. E., \& Bates, E. (1998). Bilingual performance on the Boston Naming Test: preliminary norms in Spanish and English. Brain and Language, 65, 422-440. 
Kohnert, K., \& Danahy, K. (2007). Young L2 learners' performance on a novel morpheme task. Clinical Linguistics \& Phonetics, 21, 557-569.

Kohnert, K., Windsor, J., \& Yim, D. (2006). Do language-based processing tasks separate children with language impairment from typical bilinguals? Learning Disabilities Research \& Practice, 21, 19-29.

Ku, Y. M., \& Anderson, R. C. (2003). Development of morphological awareness in Chinese and English. Reading and Writing, 16, 399-422.

Kuo, L. J., \& Anderson, R. C. (2006). Morphological awareness and learning to read: a cross-language perspective. Educational Psychologist, 41, 161-180.

Lambert, W. E. (1977). The effects of bilingualism on the individual: cognitive and sociocultural consequences. In P. A. Hornby (Ed.), Bilingualism: psychological, social, and educational implications (pp. 15-27). New York, NY: Academic Press.

Langdon, H. W. (1992). Speech and language assessment of LEP/bilingual Hispanic students. In H. W. Langdon \& L. L. Cheng (Eds.), Hispanic children and adults with communication disorders (pp. 201-271). Gaithersburg, MD: ASPEN Publishers.

Lee, H. R., Chang-Song, Y. K., Choi, Y. L., \& Lee, S. B. (2009). Lexical acquisition of Korean infants: characteristics of early expressive vocabulary. Journal of Speech \& Hearing Disorders, 18, 65-80.

Lee, K., \& Lee, H. (2005). The relationship between bilingualism and metacognitive ability. Korean Journal of Developmental Psychology, 18, 105-119.

Lynn, M. R. (1986). Determination and quantification of content validity. Nursing Research, 35, 382-386.

McLaughlin, B. (1995). Fostering second language development in young children: principles and practices. Santa Cruz, CA: National Center for Research on Cultural Diversity and Second Language Learning.

Miller, C. A., Kail, R., Leonard, L. B., \& Tomblin, J. B. (2001). Speed of processing in children with specific language impairment. Journal of Speech, Language, and Hearing Research, 44, 416-433.

Montgomery, J. W. (1993). Haptic recognition of children with specific language impairment: effects of response modality. Journal of Speech, Language, and Hearing Research, 36, 98-104.

Moon, S. B., \& Byun, C. J. (2003). Korean Kaufman assessment battery for children $(K-A B C)$. Seoul: Hakjisa.

Oetting, J. B., Rice, M. L., \& Swank, L. K. (1995). Quick incidental learning (QUIL) of words by school-age children with and without SLI. Journal of Speech, Language, and Hearing Research, 38, 434-445.

Paradis, J., Emmerzael, K., \& Duncan, T. S. (2010). Assessment of English language learners: using parent report on first language development. Jour- nal of Communication Disorders, 43, 474-497.

Park, S. (2012). A study on the literacy of underachievers. Journal of Special Children Education, 14, 27-51.

Pearson, B. Z. (2007). Social factors in childhood bilingualism in the United States. Applied Psycholinguistics, 28, 399-410.

Pearson, B. Z., Fernandez, S. C., Lewedeg, V., \& Oller, D. K. (1997). The relation of input factors to lexical learning by bilingual infants. Applied Psycholinguistics, 18, 41-58.

Restrepo, M. A. (1998). Identifiers of predominantly Spanish-speaking children with language impairment. Journal of Speech, Language, and Hearing Research, 41, 1398-1411.

Roseberry, C. A., \& Connell, P. J. (1991). The use of an invented language rule in the differentiation of normal and language-impaired Spanish-speaking children. Journal of Speech, Language, and Hearing Research, 34, 596603.

Spaulding, T. J., Plante, E., \& Vance, R. (2008). Sustained selective attention skills of preschool children with specific language impairment: evidence for separate attentional capacities. Journal of Speech, Language, and Hearing Research, 51, 16-34.

Swanson, H. L., \& Sachse-Lee, C. (2001). A subgroup analysis of working memory in children with reading disabilities domain-general or domainspecific deficiency? Journal of Learning Disabilities, 34, 249-263.

Van Kleeck, A. (1982). The emergence of linguistic awareness: a cognitive framework. Merrill-Palmer Quarterly, 28, 237-265.

Wang, M., Ko, I. Y., \& Choi, J. (2009). The importance of morphological awareness in Korean-English biliteracy acquisition. Contemporary Educational Psychology, 34, 132-142.

Welsh, M. C., \& Pennington, B. F. (1988). Assessing frontal lobe functioning in children: views from developmental psychology. Developmental Neuropsychology, 4, 199-230.

Williams, D., Stott, C. M., Goodyer, I. M., \& Sahakian, B. J. (2000). Specific language impairment with or without hyperactivity: neuropsychological evidence for frontostriatal dysfunction. Developmental Medicine \& Child Neurology, 42, 368-375.

Windsor, J., \& Kohnert, K. (2004). The search for common ground. Part I: Lexical performance by linguistically diverse learners. Journal of Speech, Language, and Hearing Research, 47, 877-890.

Windsor, J., Kohnert, K., Lobitz, K. F., \& Pham, G. T. (2010). Cross-language nonword repetition by bilingual and monolingual children. American Journal of Speech-Language Pathology, 19, 298-310. 
Windsor, J., Kohnert, K., Loxtercamp, A. L., \& Kan, P. F. (2008). Performance on nonlinguistic visual tasks by children with language impairment. Applied Psycholinguistics, 29, 237-268.

Wolter, J. A., Wood, A., \& D'zatko, K. W. (2009). The influence of morphological awareness on the literacy development of first-grade children. Language, Speech, and Hearing Services in Schools, 40, 286-298.

Yim, D. (2011). The use of nonlinguistic statistical learning as a clinical marker in bilingual children. Korean Journal of Communication Disorders, 16, $13-22$.
Yim, D., Jo, Y., Han, J., \& Seong, J. (2016). Executive function in Korean-English bilingual children with and without vocabulary delay. Communication Sciences \& Disorders, 21, 472-487.

Yim, D., Kohnert, K., \& Windsor, J. (2005). Sensitivity and specificity to LI for a non-linguistic processing task. Proceedings of the American Speech Language-Hearing Association (ASHA) Annual Convention, San Diego, CA. Yim, D., Yoon, S., \& Lee, J. (2016). Receptive vocabulary assessment in Korean-English bilingual children: cross-linguistic investigations. Communication Sciences \& Disorders, 21, 131-138. 
Yeonjoo Jo, et al. • Dynamic Assessment in Bilingual Children

Appendix 1. 한국어 및 영어 새로운 의존형태소 과제(NBMG) 선정 어휘

\begin{tabular}{ccc}
\hline & 한국어 선정 어휘 & 영어 선정 어휘 \\
\hline 1음절 & 별 & Pan \\
곰 & Lamp \\
귤 & Toast \\
감 & Block \\
약 & Bed \\
꽃 & Spoon \\
옷 & Train \\
컵 & Fish \\
책 & Clock \\
말 & Pig \\
2음절 & 양말 & Bucket \\
& 선물 & Vacuum \\
& 깃발 & Tub \\
& 선물 & Melon \\
& 칫솔 & Button \\
& 이불 & Jacket \\
& 장갑 & Pencil \\
기린 & Chicken \\
& 풍선 & Penguin \\
& 신발 & Pumpkin \\
& &
\end{tabular}

Appendix 2. 규칙이 포함된 어휘 목록

별/웅/, 곰/웅/, 귤/웅/, 감/웅/, 약/웅/, 양말/웅/, 선물/웅/, 깃발/웅/, 칫솔/웅/, 이불/웅/

별/오/, 곰/오/, 귤/오/, 감/오/, 약/오/, 양말/오/, 선물/오/, 깃발/오/, 칫솔/오/, 이불/오/ pan/ə/, lamp/ə/, toast/ə/, block/ə/, bed/ə/, bucket/ə/, vacuum/ə/, tub/ə/, melon/ə/, button/ə/

pan/pl/, lamp/pl/, toast/pl/, block/pl/, bed/pl/, bucket/pl/, vacuum/pl/, tub/pl/, melon/pl/, button/pl/

Appendix 3. 형태소 학습 단계 목록과 순서

\begin{tabular}{|c|c|c|c|}
\hline 과제 언어 & 단어 그림 & 규칙 & 단어 목록 \\
\hline \multirow{2}{*}{$\begin{array}{l}\text { 한국어 형태소 과제 } \\
\text { (KNBMG) }\end{array}$} & 사물의 반 & |-웅/ & 별/웅/, 곰/웅/, 귤/웅/, 감/웅/, 약/웅/, 양말/웅/, 선물/웅/, 깃발/웅/, 칫솔/웅/, 이불/웅/ \\
\hline & 작아진 그림 & /오/ & 별/오/, 곰/오/, 귤/오/, 감/오/, 약/오/, 양말/오/, 선물/오/, 깃발/오/, 칫솔/오/, 이불/오/ \\
\hline \multirow{2}{*}{$\begin{array}{l}\text { 영어 형태소 과제 } \\
\text { (ENBMG) }\end{array}$} & 사물의 반 & $\mid-2 /$ & pan/ə/, lamp/ə/, toast/ə/, block/ə/, bed/ə/, bucket/ə/, vacuum/ə/, tub/ə/, melon/ə/, Button/ə/ \\
\hline & 작아진 그림 & $\mid-\mathrm{pl} /$ & pan/pl/, lamp/pl/, toast/pl/, block/pl/, bed/pl/, bucket/pl/, vacuum/pl/, tub/pl/, melon/pl/, button/pl/ \\
\hline
\end{tabular}


Appendix 4. 규칙1이 적용된 그림

단어 확인 단계 - 사물 전체 그림

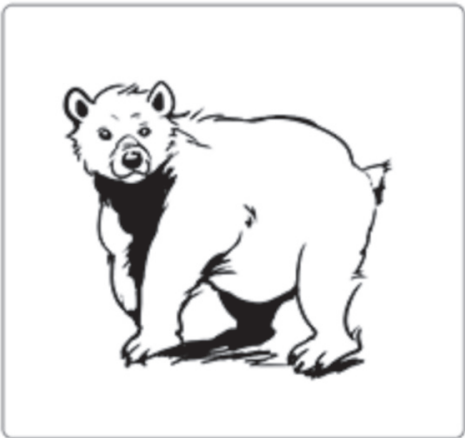

아동의 대답 “곰"
형태소 학습 단계- 사물의 반(규칙1)

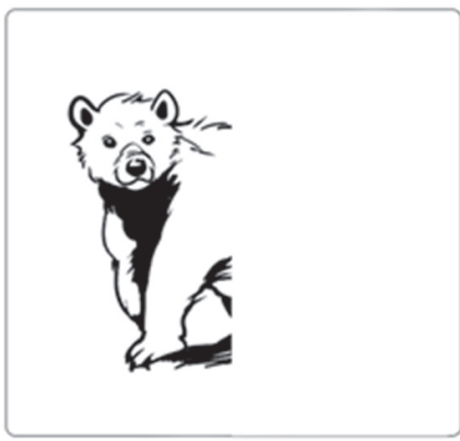

컴퓨터 녹음 파일 “곰/웅/”

Appendix 5. 규칙2가 적용된 그림

단어 확인 단계 - 사물 전체 그림

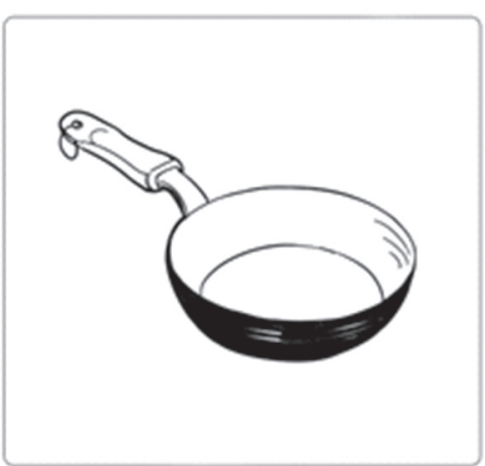

아동의 대답 "pan"
형태소 학습 단계 - 작아진 사물(규칙2)

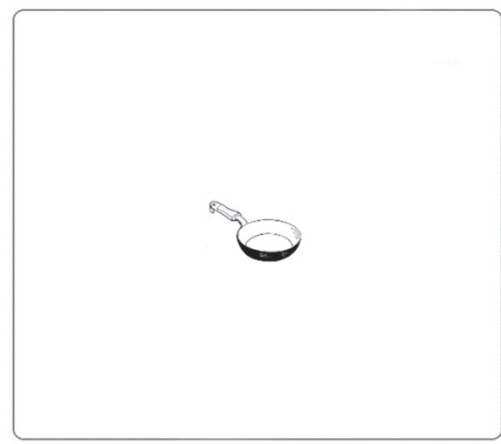

컴퓨터 녹음 파일 "pan/pl/" 
Yeonjoo Jo, et al. • Dynamic Assessment in Bilingual Children

Appendix 6. 일반화 단계 목록과 순서

\begin{tabular}{|c|c|c|c|c|}
\hline \multicolumn{2}{|c|}{ 한국어 형태소 과제(KNBMG) } & \multirow{2}{*}{$\begin{array}{l}\text { 규칙 } \\
\text { 규칙1 }\end{array}$} & \multicolumn{2}{|c|}{ 영어 형태소 과제(ENBMG) } \\
\hline 1 & 꽃/웅/ & & 1 & spoon/ə/ \\
\hline 2 & 옷/웅/ & 규칙1 & 2 & train/o/ \\
\hline 3 & 우산/웅/ & 규칙1 & 3 & pumpkin/ə/ \\
\hline 4 & 컵/오/ & 규칙2 & 4 & $\mathrm{fish} / \mathrm{pl} /$ \\
\hline 5 & 책/오/ & 규칙2 & 5 & clock/pl/ \\
\hline 6 & 말/오/ & 규칙2 & 6 & jacket/pl/ \\
\hline 7 & 장갑/웅/ & 규칙1 & 7 & pencil/a/ \\
\hline 8 & 기린/웅/ & 규칙1 & 8 & fish/ə/ \\
\hline 9 & 풍선/오/ & 규칙2 & 9 & chicken/pl/ \\
\hline 10 & 신발/오/ & 규칙2 & 10 & penguin/pl/ \\
\hline
\end{tabular}

Appendix 7. 1차 예비실험 형태소 학습순서

\begin{tabular}{|c|c|c|}
\hline & 한국어 형태소 과제(KNBMG) & 영어 형태소 과제(ENBMG) \\
\hline 규칙1 3개 & 별/웅/, 곰/웅/, 귤/웅/ & pan/ə/, lamp/ə/, toast/ə/ \\
\hline 규칙2 3개 & 별/오/, 곰/오/, 귤/오/ & pan/pl/, lamp/pl/, toast/pl/ \\
\hline 규칙1 2개 & 감/웅/, 약/웅/ & block/ə/, bed/ə/ \\
\hline 규칙2 2개 & 감/오/, 약/오/ & block/pl/, bed/pl/ \\
\hline 규칙1 3개 & 양말/웅/, 선물/웅/, 깃발/웅/ & bucket/ə/, vacuum/ə/, tub/ə/ \\
\hline 규칙2 3개 & 양말/오/, 선물/오/, 깃발/오/ & bucket/pl/, vacuum/pl/, tub/pl/ \\
\hline 규칙1 2개 & 칫솔/웅/, 이불/웅/ & melon/ə/, button/ə/ \\
\hline 규칙2 2개 & 칫솔/오/, 이불/오/ & melon/pl/, button/pl/ \\
\hline
\end{tabular}




\section{국문초록}

\section{한국어-영어 이중언어 아동의 새로운 의존형태소 일반화 과제(NBMG) 수행 능력}

\section{조연주 · 임동선}

이화여자대학교 대학원 언어병리학과

배경 및 목적: 본 연구에서는 새로운 의존형태소 일반화 과제(Novel Bound-Morpheme Generalization, NBMG)를 한국어와 영어로 개발하여 이중언어 사용 일반 아동, 단일언어 일반 아동, 단일언어 언어발달지연 아동의 형태소 학습 능력을 살펴보고, 집단 간 비교를 통하여 NBMG가 언어발달지연 아동 선별에 효과가 있는지 확인해 보고자 하였다. 방법: 본 연구에 참가하는 만4세 6개월-만7세 이중 언어 일반 아동 30 명, 단일언어 일반 아동 30 명, 단일언어 언어발달지연 아동 20 명이며, 이중언어 아동에게는 한국어 의존형태소 일반 화 과제(KNBMG)와 영어 의존형태소 일반화 과제(ENBMG)를 실시하였고, 단일언어 아동에게는 KNBMG만 실시하였다. 결과: 이중 언어 일반 아동, 단일언어 일반 아동, 단일언어 언어발달지연 아동의 KNBMG 수행력에서 단일언어 언어발달지연 아동이 이중언어 일 반 아동과 단일언어 일반 아동에 비해 통계적으로 유의하게 낮은 수행력을 나타냈다. 또한 이중언어 일반 아동의 KNBMG점수는 한국 어 수용어휘력 합산점수와 유의한 상관관계를 보였으며, KNBMG점수와 ENBMG점수도 유의한 상관관계를 보였다. 논의 및 결론: $\mathrm{NBMG}$ 는 언어발달지연 아동을 선별하는 데 효과적인 과제로써, $\mathrm{KNBMG}$ 수행력이 낮을 경우 아동의 언어발달지연을 의심해 볼 수 있 다. 그러므로 이중언어 아동과 언어재활사가 공유하는 한 가지 언어로 NBMG를 제작하여 아동의 언어 능력을 측정할 수 있다는 가능 성을 제시해 주었다.

핵심어: 이중언어, 역동적 평가, 언어장애, 학습능력, 형태소

본 연구는 2015년도 이화여자대학교 교내연구비에 의한 연구임.

\section{참고문헌}

김미배, 배소영(2007). 유치원, 초등 2,4학년의 낱말재인 및 음운인식 능력. 언어치료연구, 16, 89-107.

김순호, 정경희(2015). 초등 저학년 읽기학습부진아동의 형태소인식과 읽기능력. 언어치료연구, 24, 35-47.

김영태, 홍경훈, 김경희, 장혜성, 이주연(2009). 수용·표현어휘력검사(REVT). 서울: 서울장애인종합복지관.

문수백, 변창진(2003). K-ABC 교육·심리측정도구(Korean-Kaufman assessment battery for children). 서울: 학지사.

박순길(2012). 학습부진아동의 문식성 연구. 특수아동교육연구, 14, 27-51.

이귀옥, 이혜련(2005). 아동의 이중언어경험과 상위인지능력의 관계: 기수성을 중심으로. 한국심리학회지: 발달, 18, 105-119.

이귀옥, 이혜련(2008). 한국어-중국어 이중 언어 아동의 한국어 발달: 복문발달을 중심으로. 아동학회지, 29, 1-12.

이하원, 최경숙(2009). '한국어-영어’ 동시습득 이중언어아동의 한국어 발달: 어미발달을 중심으로. 한국심리학회지: 발달, 22, 57-71.

이희란, 장유경, 최유리, 이승복(2009). 한국 아동의 어휘 습득. 언어치료연구, $18,65-80$.

임동선, 윤사라, 이지연(2016). 교차언어 연구를 통한 한국어-영어 이중언어아동의 수용어휘력 평가. 언어청각장애연구, 21, 131-138.

임동선, 조연주, 한지윤, 성지민(2016). 한국어-영어 이중언어사용 아동의 어휘발달지연 유무에 따른 집행기능 비교. 언어청각장애연구, 21, 472-487.

정경희(2014). 1-3학년 학령기 아동의 형태소인식과 읽기능력. 언어청각장애연구, 19,21-30.

홍성미, 임동선(2014). 학습 및 기억과제를 통한 이중언어아동의 언어발달지체 평가. 언어청각장애연구, 19, 31-44.

황혜신, 황혜정(2000). 이중언어(한국어-영어)를 하는 아동의 언어능력발달에 관한 연구. 아동학회지, 21, 69-79. 